\title{
Utilization of Degraded Saline Habitats and Poor-quality Waters for Livelihood Security
}

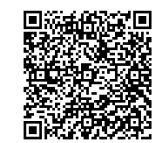

\author{
JC Dagar* \\ Ex-ADG (NRM), New Delhi, India
}

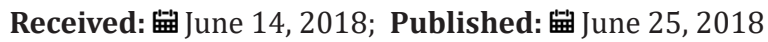

*Corresponding author: JC Dagar, Ex-ADG (NRM), Krishi Anusandhan Bhawan-II, Pusa, New Delhi-110012, Urban Estate, Karnal-132001, India

\begin{abstract}
The world population is estimated to cross 7.6 billion and to develop agricultural strategies to feed all people represents as one of the biggest challenges of this century. We have limited land and water resources; therefore need to develop all these resources carefully. Nearly one billion hectares of arid and semiarid areas of the world are salt-affected and remain barren. These soils are universally low in fertility and not suitable for conventional agricultural use. Irrigation without adequate drainage is leading to waterlogging and secondary salinization. Further, in most of these regions, the groundwater aquifers are saline. Usually cultivation of conventional arable crops with saline irrigation has not been sustainable. To bring these wastelands under sustainable productive system and use poor-quality waters judiciously in agriculture, we need to evolve innovative technologies and domesticate stress tolerant halophytes of high economic value. Further, saline agroforestry needs to be given preference as salt-tolerant forest and fruit trees, forage grasses, medicinal and aromatic and other non-conventional crops can be equally remunerative. In coastal areas, mangrove-based aquaculture needs to be developed. The littoral vegetation not only protects the shores and provides wood for fuel, fodder, thatching material, and honey for coastal population but also creates substratum, which provides shelter to a variety of animals. The ecosystem also helps in fish production and plays a key role in food web. Such uses have additional environmental benefits including carbon sequestration, biodiversity conservation, and biological reclamation. In this write up, some of these aspects have been discussed in brief.
\end{abstract}

Keywords: Salt-affected soils; Biosaline agriculture; Non-conventional; Halophytes; Mangroves; Saline irrigation; Carbon sequestration

\section{Introduction}

The world population is estimated to have reached 7.6 billion as of December 2017 and the United Nations predicted a population increase to 9.1 billion by 2050 and 11.8 billion by the year 2100 (https://en.wikipedia.org), putting huge pressure on food availability. By the year 2050, another 1 bilion Mg of cereals and 200 million Mg of extra livestock products need to be produced every year. The imperative for such agricultural growth is strongest in developing countries, where the challenge is not just produce food but to ensure that the people have access that will bring them food and nutritional security. So, agriculture strategies for feeding all people represent one of the biggest challenges in this century. Therefore, there is to be enormous demographic and economic pressure on all nations to meet ever-increasing demands of people. Besides ever increasing population pressure, some other facts are aggravating this demand [1], which include:

a) The increase of land occupation for biofuel supply deviating arable soils from food crops,

b) Soil fatigues posed by post green revolution,

c) Rise of soil degradation due to salinity, and

d) Challenges posed by episodes of extreme environmental conditions, generally called "climate change events".

Recent trend in climate variability poses a serious threat to sustainability of agriculture, hence food security across the globe especially in developing countries. Land degradation due to salinity and waterlogging, land fragmentation, labour problems and over exploitation of natural resources, further accentuates situation in these countries. Nearly 1 billion hectares of arid and semiarid areas of the world are salt-affected and remain barren due to salinity 
or water scarcity. Salinity, emerging as a major land degradation factor due to inefficient irrigation methods in most of the canal commands. Nearly 60 million ha of land area is already severely waterlogged in canal command areas. The problem is more severe in areas underlain with poor quality groundwater. In most of arid and semiarid regions, the groundwater aquifers are saline. Usually cultivation of conventional arable crops with saline irrigation has not been sustainable.

The waterlogging and inundation in landscapes are expected to increase with impending climate changes. Aberrations in rainfall, melting of glaciers and more frequent chances of sever tropical storms with rise of temperature are also likely to increase inundations in whole south Asia, and particularly in the Ganges, Brahmaputra and Meghna basins. Possible rise in sea level, high tides, storm surges and even increased subsoil seawater intrusion will alter hydrological cycle, increase soil and groundwater salinity and also risk of inundation in coastal areas of tropical regions. Though poor-quality groundwater available in dry land aquifers and urban sewage provides an opportunity for irrigation to sustain agriculture development and meet the increasing demands of food, forage, fuel wood and timber; but also poses risk of salinity build up adopting these means.

However, adopting saline irrigation depends on crop salttolerance, soil and water characteristics, climatic conditions, availability of fresh water, and management practices influencing soil water crop atmosphere continuum and the saline water irrigation economics [2-4]. All this suggests for timely development of suitable measures for adaptation and mitigation of adverse impacts of climate change on biosaline agriculture. Further, with the increasing demand for good-quality land and water for urbanization and development projects in the future, which are taking place at rapid pace, agriculture will be pushed more and more to the marginal lands, and use of poor quality waters for irrigation is inevitable. To bring the salt-affected wastelands under sustainable productive system and use poor-quality waters judiciously in agriculture, we need to evolve innovative technologies and domesticate stress-tolerant halophytes of high economic value.

In recent years, however, the attention is being paid worldwide to accommodate the salt-tolerant species of economic importance for highly saline degraded areas including coastal marshes and irrigating them with saline water. The scopes of many of these species of high economic value for saline and sodic habitats along with their management and utilization have been discussed in this paper. Potential of afforestation and agroforestry in carbon sequestration particularly in salt-affected soils has been worked out. Therefore, growing forest and fruit trees, grasses and nonconventional crops of high economic value including medicinal and aromatic plants on salt-affected soils or using saline water for irrigation is a sustainable option of utilizing these degraded resources. Some of these opportunities have been discussed in this write up.

\section{Potential Salt-tolerant Resources}

Based on their genetic potential to counter the root zone salinity, the plants differ in their capacity to adapt to saline habitats. The capacity to lower the osmatic potential of cell sap, salt exclusion, salt secretion, and succulence are common but differently expressed attributes of salt-tolerant vegetation. Thus, the plants which are able to grow successfully with sufficient growth and complete life cycle on high saline habitats and possess special adaptive procedures are called halophytes. Many of these sustain saline irrigation and produce economic biomass and products. For halophytes succeed as irrigated crops, Glenn [5] mentioned four basic conditions essential, which include high yield potential; the irrigation needs must not exceed the conventional crops and be harmless to the soil; the products from halophyte crops must be able to replace the conventional crop products; and high salinity agriculture must be applicable to the existing agricultural infrastructure. During last four decades many studies have been undertaken to domesticate and popularize the halophytic crops in unfavourable conditions [2, 6-12] showing their potential in changed environment.

The potentiality of using halophytes in commercial exploitation, though still limited, is already being applied for some species. The search for potential halophytes have resulted in identification of many genera such as Acacia, Anacardium, Arthrocnemum, Atriplex, Avicennia, Batis, Brachiaria, Bruguera, Calophyllum, Capparis, Carandas, Cassia, Casuarina, Ceriops, Chloris, Citrulus, Coccoloba, Cressa, Crithmum, Distichlis, Eucalyptus, Glycyrrhiza, Grindelia, Juncus, Kochia, Kosteletzkya, Leptochloa, Leucaena, Limonium, Lumnitzera, Maireana, Matricaria, Nypa, Pandanus, Pongamia, Panicum, Plantago, Porterasia, Prosopis, Rhizophora, Salicornia, Salvadora, Simmondsia, Sonneratia, Spergularia, Sporobolus, Suaeda, Tamarix, Taxodium, Terminalia, Thinophyrum, Vetiveria, Xylocarpus, Ziziphus and Zostera. There may exist as many as 250 potential staple halophytic crops [13]. However, adaptability of any potential halophyte to saline habitats and its economic use decides the acceptability of it in different regions. Also, the project "Greening Eritrea" from the Seawater Foundation (http://www. seawaterfoundation.org) represents an example of how to convert a decertified region into a useful soil. About 2600 halophytic species are known and only few are extensively studied for their potential in agriculture and as biological resources with economical potential as source of food, oils, flavours, gums, resins, pharmaceuticals, and fibres [8,14-16], or with environmental potential for protection and conservation of ecosystems [17-19]. While documenting biodiversity of halophytes, Dagar and Singh [11] reported 1140 salt-tolerant flowering species under 541 genera and 131 flowering families from Indian salt-affected and waterlogged habitats; out of which 988 having economic uses. Some of the potential halophytes are discussed as below: 


\section{Halophytes as Food Crops}

(Bio) saline agriculture can provide food in many ways, especially in areas where traditional agriculture cannot be profitable. Appropriate species can be domesticated and their seeds, fruits, roots, tubers or foliage can be used directly or indirectly as food. Aronson [8] reported that at least 50 species of seed bearing halophytes are potential sources of grains and oil. Since long, many species are used in variety of dietary ingredients but their scientific exploration developed only in the latter half of the $20^{\text {th }}$ century [21,22]. Species such as Distichlis palmeri, Zostera marina, Chenopodium quinoa, C. album, Salicornia bigelovii, Diptotaxis tenuifolia, and many others have been established as food crops. These can be explored commercially using sea water for irrigation.

The Eelgrass (Zostera marina) grows in the Gulf of California; seed contains $50 \%$ starch, $13 \%$ protein and $1 \%$ fat; is comparable with wheat. The Palmer salt grass (Distichlis palmeri) used as food by natives (contains protein contents $8.7 \%$ and fibre higher than wheat) has been used to develop grain crop by NyPa, Inc. having well balanced amino acid composition. Alkali Sacaton (Sporobolus airoides), is another candidate for domestication. Pearl millet (Pennisetum typhoides) grows well on sand dunes and tolerates EC of $27-37 \mathrm{dS} \mathrm{m}^{-1}$ of saline water used for irrigation, can be grown as a food crop with seed yield up to $1.6 \mathrm{Mg} \mathrm{ha}^{-1}$ and straw as fodder up to $6.5 \mathrm{Mg} \mathrm{ha}^{-1}$. Aster tripolium (also known as Sea Aster or Sea Spinach) grows in temperate regions, close to the coast mainly in the salt meadows and estuaries, is a very productive and can be cut several times with a regrowth of young shoots every 3-4 weeks, has now become a delicacy in the Netherlands. Some interesting research has been carried out concerning the response of Aster tripolium and Puccinellia maritima to atmospheric carbon dioxide enrichment and their interactions with flooding and salinity [22].

The perennial Seashore mallow (Kosteletzkya virginica) can produce $1.5 \mathrm{Mg} \mathrm{ha}^{-1}$ grain of high protein (32\%) and oil (22\%) content making it an excellent candidate as a grain or oil crop [15]. Many Acacia species (A. aneura, A. coriacea, A. cowleana, A. dictyophleba) produce seed that are rich in nutrients with higher energy, protein and fat contents than wheat or rice. A. aneura is a potential oil crop ( $37 \%$ fat), whereas A. dictyophleba is a potential grain crop with high protein (26.8\%) content [15]. The use of Suaeda maritima, Salichornia brachiata and Salsola baryosma in sajji/papar industry in Rajasthan and Gujarat is well known. Salicornia bigelovii (having CAM metabolism), is a very well studied species, cultivated for its oil seed (both for human and animal use) and straw. The seed yield is $\sim 2 \mathrm{Mg} \mathrm{ha}^{-1}$, similar in quality to soybean, contain $28 \%$ oil rich in polyunsaturated fatty acids (linoleic acid $74 \%$ of total) and $31 \%$ protein [4] and a biomass of $18 \mathrm{Mg} \mathrm{ha}^{-1}$, over a 200 days cycle. The residual seed meal is very rich in protein $(\sim 33 \%$ crude protein). Salicornia species including those native to the Arabian Gulf Region (e.g. S. herbacea), produce an edible, safflower like seed oil and plant material about $20 \mathrm{Mg} \mathrm{ha}^{-1}$ when irrigated with sea water, used as fodder for sheep and goats.
At least 50 species of seed bearing halophytes are potential sources of edible oil and proteins. Salicornia bigelovii, Terminalia catappa, Suaeda moquinii, Kosteletzkya virginica, Batis maritima, Chenopodium glaucum, Crithmum maritimum and Zygophyllum album are a few examples. Seeds of various halophytes, such as Suaeda fruticose, Arthrocnemum macrostachyum, Salicornia brachiata, Halogeton glomeratus, Kochia scoparia and Haloxylon stocksii possess a sufficient quantity of high quality edible oil with unsaturation ranging from $70-80 \%$. Seeds of Salvadora persica and S. oleoides contain $40-50 \%$ fat and are a good source of lauric acid, a potential substitute for coconut oil [1]. Seed oil (52\%) from Indian almond nut (Terminalia catappa) has been found suitable for consumption. The physicochemical properties of the seed oil indicated that it is edible, drying and suggested its suitability for industrial purposes as well as the nutritional potentials of the nut, which could serve as an alternative food ingredient for unsaturated vegetable oil. The suitability of coconut (Cocos nucifera) oil for food consumption and hair oil is well established.

The annual herb Quinoa (Chenopodium quinoa), is one of the staple food of native South Americans, produces nutritious seeds (30\% of dry weight of the plant or $2.5 \mathrm{Mg} \mathrm{ha}^{-1}$ ) with higher protein contents and amino acid composition compared to wheat. C. album, is another nutrient rich herb commonly used as green vegetable during winter in Indian sub-continent. Seaside purslane (Sesuvium portulacastrum), Common purslane (Portulaca oleracea), sea fennel (Crithmum maritima), Atriplex triangularis, A. hortensis, Suaeda maritima, Amaranthus spinose, A. virdis and many other herbs are commonly used as green vegetables in India. Species such as Cochlearia officinalis, Crambe maritima, Crithmum maritimum, inula crithmoides, Mesemyranthemum crystallinum, Plantago coronopus, and Tetragonia tetragonoides are used as fresh salad or cooked vegetables. Wild water chestnut (Eleocharis dulcis) tubers are cooked or pounded to meal. Similarly, the roots and stems of saltwort (Batis maritima) can be used for food; the plant produces up to $17 \mathrm{Mg} \mathrm{ha}^{-1}$ of dry biomass using seawater for irrigation. Diplotaxis tenuifolia, also is a promising species for saline agriculture and has a potential for food (salad) and forages. Beet root (Beta vulgaris) is widely used as vegetable, salad and also a source of forage as well as sugar. Pods of salt-tolerant tree Prosopis cineraria are consumed as vegetable when raw and animal feed when ripe.

Though the fruit trees are among the most sensitive to salinity, researchers have been able to identify certain halophytic species that can be used either as rootstocks or as grafts to produce economic fruit yields using saline water for irrigation [12]. Ziziphus nummularia, a salt-tolerant species with small berries (edible) can be used as a rootstock for $Z$. mauritiana that can produce larger berries. Similarly, Manilkara hexandra can be used as a rootstock for grafting M. zapota that can produce large fruits. Some trees such as date palm (Phoenix dactylifera) yielding edible fruits, Carissa carandas (fruit pickeled) and Capparis decidua (fruit pickled) are well-known for their salt tolerance. Fruits of coastal Morinda 
citrifolia are consumed, pickled and used for extracting juice. Large fruits of Pandanus are staple food for coastal population of Andaman-Nicobar Islands. They also consume fruits of Artocarpus heterophyllus (as vegetable and fruits), Annona squamosa, A. glabra, local banana (varieties of Musa acuminata, M. textilis, M. paradisiaca), Ardisia solanacea and A. andamanica. The tuber roots of Manihot esculentum along with several Dioscorea roots are also consumed by them. Coconut (Cocos nucifera) is the life tree for the aborigines. Palmirah palm (Borassus flabellifer) is widely used along Andhra coast for toddy, jiggery, vinegar, beverage, as a juice for sugar making, and its radicles (after germination of fruit) are eaten roasted. Many other wild species are consumed as food by locals. For example, seeds of Cycas rumphii, fruits of mangrove Avicennia marina, fruit pulp of Balanites roxburghii, leaves of Basella album, fruits of Opuntia, Diospyros ferrea, Syzygium cuminii. S. samatangense, Rhodamania trinervia and Ximenia americana are consumed. Other potentially useful genetic resources as fruit trees include species of Lycium, Santalum acuminatum (distributed widely in Australia), Mangifera andamanica (endemic in Andamans), M. camptosperm, and Coccoloba uvifera.

\section{Halophytes as Fodder Crops}

Halophytes have been used as forage in arid and semiarid parts of the world for millennia. Large number of salt-tolerant species has been incorporated in pasture improvement programs across the globe. Among trees, species of Acacia (ampliceps, bivenosa, cyclopes, eburnea, holosericea, leucophloea, nilotica, salicina, saligna, senegal, tortilis, victoria), Prosopis (alba, chilensis, cineraria, glandulosa, juliflora,pallida, tamarugo) and Leucaena leucocephala are widely cultivated in isolation or as agroforestry tree on field boundary or a constituent of silvo-pastoral system. Among other trees grown on salt-affected lands and used as forage for cattle, goats, sheep and camel include Ailanthus excels, Anogeissus pendula, Azadirachta indica, Balanites roxburghii, Calophospermum mopane, Cordia rothii, Dalbergia sissoo, Dichrostachys cinerea, Ficus spp., Parkinsonia aculeata, Pithecellobium dulce, Salvadora persica, S. oleoides, Tamarindus indica and Ziziphus mauritiana. Among shrubs, saltbushes (species of Atriplex) are common throughout the Middle East region and Atriplex. Mairiena brevifolia, Halosarica pergranulata, $H$. lepidosperma, $H$.

Indica subsp bidens and Russian thistle (Salsola iberica) are common Australian species, now also introduced in many other countries; while Haloxylon persicum, H. salicornicum, Kochia indica and Ziziphus nummularia are common Indian forages. Among grasses Kallar grass (Leptochloa fusca), Silt grass (Paspalum vaginatum), salt grass (Distichlis spectata), channel-millet (Echinochloa turnerana), cord-grasses (Spartina alterniflora, S. foliosa, S. patens), Rhodes grass (Chloris gayana) and wheat grass (Elytriga elongata) are common potential sources for grazing. Indian grasses of fodder value include Leptochloa fusca, Chloris gayana, C. barbata, Aeluropus lagopoides, Cynodon dactylon, Bothriochloa pertusa, Dichanthium annulatum, Brachiaria mutica, Paspalum conjugatum, Panicum laevifolium, P. maximum and many others.
These are also constituents of silvo-pastoral systems developed on waterlogged saline lands in different agro-climatic regions $[11,23]$.

In India, species of Phragmites, Rumex, Polygonum, Typha, Coix, Brachiaria, Pasalum, Echinochloa, Scirpus, Cyperus, Saccharum and Vetiveria are among the predominant herbaceous/grass species and species of Salicornia, Suaeda, Haloxylon, Salsola, Tamarix and Ipomoea are prominent shrubs or under-shrubs found in waterlogged saline situations. Paspalum vaginatum has an amazing ability to thrive in wet salty areas. L. fusca, B. mutica and species of Paspalum are excellent fodder grasses, which can be cultivated under waterlogged situations in Indian subcontinent. Species of Atriplex, Kochia, Suaeda, Salsola, Haloxylon and Salvadora are prominent forage shrubs of saline regions and relished by camel, sheep and goats.

\section{Halophytes as Fuel Crops}

The criteria for selecting potential genetic resources for use as fuel wood in saline environment may also include [15]: a rapid rate of growth and regrowth after cutting; easy establishment in salty environment; wide adaptation; and if possible, diverse use besides the fuel wood (e.g., wind breaks, livestock fences, nitrogen fixing, shade for forage crops, etc.). The most common genera used as fuelwood include [15]: Acacia (ampliceps, crassicarpa, cyclops, floribunda, longiflora, oraria, pendula, pycnantha, redolens, retinodes, saligna, sophorae, stenophulla), Casuarina (camaldulensis, cristata, equistefolia, glauca, obesa), Eucalyptus (angulosa, camaldulensis, calophylla, erythrocorys, incrassate, halophila, occidentalis, sargentii, spathulate, kondininensis, largiflorens, neglecta, tereticornis, loxophelba) and Prosopis (alba, articulata, cineraria, chilensis, nigra, flexuosa, juliflora, pallida, tamarugo). In India, Tamarix articulata, Acacia nilotica and Prosopis juliflora are most commonly used. In coastal areas, mangrove and their associate species are commonly used as fuel wood.

Very few plants have been identified as potential source of liquid fuels under saline conditions. Among tree borne oil seeds (TBOS) Pongamia pinnata (36\% seed oil), Jatropha curcas (37\%), J. gossypifolia (40\%), J. podagrica (35\%), Aphanomixis polystachya (38\%), Calophyllum inophyllum (51\%), Sapium baccatum (49\%) and Simaruba glauca (53\%) are potential coastal plants [24]. Sugar beet (Beta vulgaris) and nipa palm (Nypa fruticans) are also among other potential species. The halophytes Tamarix chinensis, Phragmites australis, Spartina alterniflora and species of Miscanthus have been evaluated as bio-fuel crops for ethanol production in the coastal zone of China [25]; while many others such as Halopyrum mucronatum, Desmostachya bipinnata, Phragmites karka, Typha domingensis and Panicum turgidum are grown in coastal regions of Pakistan as source of bio-ethanol [26]. In addition, Kallar grass (Leptochloa fusca) has been identified as a source of gaseous fuel and the energy yield per hectare was estimated at $15 \times 10^{6} \mathrm{Kcal}$ [15]. Screw pine (Pandanus fascicularis), quite predominant along Indian coast, is rich in methyl ether of betaphenyethyl alcohol and used as a perfume and flavouring ingredient. Simmondsia chinensis yields oil like sperm whale from its seeds, is viable salt-tolerant 
commercial plant for dry regions. Similarly, Salvadora persica, Ricinus communis and Pongamia pinnata yield commercial oils and can be explored economically. Euphorbia antisyphilitica has been found a potential petro-crop producing huge biomass on sandy soils irrigating with saline water of EC $10 \mathrm{dS} \mathrm{m}^{-1}$ [27].

\section{Essential Oils}

The male flowers of screw pine (Pandanus fascicularis) are a source of perfume and other flavouring ingredients. Flowers of winter annual Matricaria chamomilla (which can be cultivated with saline water) and Mentha (M. arvensis, M. piperita) both grow on saline and alkali soils, produce essential oil. Dagar [28] evaluated agronomic practices of lemon grass (Cymbopogon flexuosa) applying saline irrigation and identified suitable cultivars; Cutivar RRL 16 and OD 58 performed the best followed by Premna and OD 19 and rest being comparatively sensitive. Other plants with potential utilization in saline soils for production of essential oils include Cymbopogon nardus, C. winterianus, C. martini, Tagetus minuta, Ocimum sanctum, 0 . kilimandscharicum, Anethum graveolens and Vetiveria zizanioides.

\section{Gums, Oils and Resins}

Salt-tolerant plants for the production of gums and resins include Acacia nilotica, A. senegal, Butea monosperma, Sesbania bispinosa, S. sesban, S. speciosa, Plantago crassifolia, Althaea officinalis and cluster bean (Cyamopsis tetragonoloba) cultivated with saline water up to $10 \mathrm{dS} \mathrm{m}^{-1}$. The resinous perennial shrubs Grindelia camporum, G. humilis, G. stricta, G. latifolia and G. integrifolia produce diterpene acid resins. Seed of Jojoba (Simmondsia chinensis) contain a unique oil resembling sperm whale can be cultivated with saline water of EC $10 \mathrm{dS} \mathrm{m}^{-1}$. The perennial desert shrub guayule (Parthenium argenatum) is a source of natural rubber.

\section{Pulp and Fibre}

A number of salt-tolerant plants are being used as source of pulp and fibre. These include species of Pandanus, Hibiscus cannabinus, H. tiliaceous, Phragmites australis, P. karka, Juncus rigidus, J. acutus, Typha domingensis and grass Urochondra setulosa. There are many other grasses and sedges contributing to pulp resources.

\section{Bioactive Derivatives}

Valuable extracts from seed, leaves and bark of a number of halophytes have been characterized and used in health industry [14]. Coastal evergreen tree Alexandrian laurel (Calophyllum inophyllum) is a source of a complex phenyl coumarin used as Anti-inflammatory agent. The fruits of Balanites roxburghii, are a potential source of diosgenin, a precursor for the synthesis of a number of steroidal drugs [15]. Indian neem tree (Azadirechta indica) produces oil, used for soap making and its seed extracts are effective insecticides. Oil from mangrove Cynometra ramiflora has antibiotic properties and used in skin diseases. Salt-tolerant shrub Adhatoda vasica and seed of Annona glabra also possess insecticidal properties. Medicinal uses of some halophytes are shown in Table 1.
Table 1: Some important halophytes used as medicinal value.

\begin{tabular}{|c|c|}
\hline Species & Medicinal use \\
\hline Acanthus ilicifolius & $\begin{array}{l}\text { In rheumatism, neuralgia, paralysis, asthma and } \\
\text { as blood purifier }\end{array}$ \\
\hline A. volubilis & Dressing boils and wounds. \\
\hline Achyranthes aspera & In asthma, renal dropsis \\
\hline Acrostichum aureum & Applied on wounds and boils \\
\hline Adhatoda vasica & In asthmatic problems \\
\hline Aloe barbadensis & Piles, rheumatism, boils and stomach problems. \\
\hline Barringtonia acutangula & In diarrhoea, toothache \\
\hline B. racemosa & In cough, asthma, diarrhoea, jaundice \\
\hline Calophyllum inophyllum & Seed oil in rheumatism, skin diseases and leprosy \\
\hline Calotropis procera & $\begin{array}{l}\text { In skin diseases, tumours, piles, as abortifacient } \\
\text { and anticoagulant }\end{array}$ \\
\hline Capparis decidua & $\begin{array}{c}\text { To cure cough, asthma, inflammations, cardiac } \\
\text { troubles and biliousness }\end{array}$ \\
\hline Cerbera manghas & In rheumatism \\
\hline Citrullus colocynthis & In jaundice, rheumatism and urinary diseases. \\
\hline Clerodendrum inerme & In malarial fever as substitute to quinine \\
\hline Cress cretica & As tonic, aphrodisiac, stomachic \\
\hline Cynometra ramiflora & In leprosy, scabies and cutaneous diseases \\
\hline Heritiera fomes & To cure piles \\
\hline H. littoralis & In diarrhoea and dysentery \\
\hline Jatropha curcas & $\begin{array}{l}\text { In diarrhoea, toothache, piles, rheumatism and } \\
\text { skin diseases }\end{array}$ \\
\hline Kochia indica & Cardiac stimulant \\
\hline Pandanus odoratissimus & $\begin{array}{l}\text { In leprosy, scabies, diseases of heart, oil as } \\
\text { antispasmodic }\end{array}$ \\
\hline Pongamia pinnata & $\begin{array}{l}\text { In diarrhoea, cough, leprosy, gonorrhoea, } \\
\text { rheumatic pains }\end{array}$ \\
\hline Ricinus communis & In boils, sores, lumbago \\
\hline Salsola baryosma, S. kali & $\begin{array}{l}\text { Possess anthelmintic, emmenagogue, diuretic } \\
\text { properties; ash for itch }\end{array}$ \\
\hline $\begin{array}{l}\text { Salvadora persica, } S \text {. } \\
\text { oleoides }\end{array}$ & $\begin{array}{l}\text { In cough, rheumatism, suppositories, toothache } \\
\text { and piles. }\end{array}$ \\
\hline Solanum surattense & In cough, asthma, sore throat, rheumatism. fever \\
\hline Sonneratia caseolaris & As vermifuge \\
\hline Suaeda fruticosa & As emetic and to cure sores on camel back \\
\hline $\begin{array}{c}\text { Tamarix articulata, } T \text {. } \\
\text { troupii }\end{array}$ & $\begin{array}{l}\text { In eczema, ulcers, piles, sore throat, diarrhoea, } \\
\text { liver disorders }\end{array}$ \\
\hline Terminalia catappa & In cutaneous diseases \\
\hline Thespesia populnea & In stomach trouble \\
\hline $\begin{array}{l}\text { Trianthema } \\
\text { portulacastrum }\end{array}$ & $\begin{array}{l}\text { In asthma, amenorrhoea, dropsy, rheumatism, } \\
\text { liver problems and as abortifacient }\end{array}$ \\
\hline Tribulus terrestris & $\begin{array}{l}\text { As tonic, diuretic and in painful micturition and } \\
\text { calculous affections }\end{array}$ \\
\hline Vetiveria zizanioides & $\begin{array}{l}\text { In rheumatism, fever, headache, toothache and } \\
\text { as tonic }\end{array}$ \\
\hline Withania somnifera & In asthma, cough \\
\hline $\begin{array}{l}\text { X. moluccensis, } \\
\text { Xylocarpus granatum, }\end{array}$ & In dysentery and breast tumours \\
\hline Ziziphus nummularia & In skin diseases, cold, cough, biliousness \\
\hline Zygophyllum simplex & $\begin{array}{l}\text { It has cardiac properties and applied in eye } \\
\text { diseases }\end{array}$ \\
\hline
\end{tabular}


Catharanthus roseus withstands EC of $12 \mathrm{dS} \mathrm{m}^{-1}$ and produces an alkaloid used in the treatment of leukemia [14]. Halophytes Salsola richteri and S. kali are sources of salsolinol and salsolidine, respectively; and $S$. pestifer is a source of carotene, whereas, $S$. pestifer and S. gemmascens are sources of ascorbic and citric acids [15]. A kind of soda is obtained in large quantities from species of Suaeda, Salicornia, Salsola and Haloxylon, used in soap making and in glass industry. Seed of Salvadora persica and S. oleoides yield 40-50\% fat, rich in lauric acid and also used in soap industry. Seed oils from salt-tolerant Azadirechta indica, Terminalia billirica, T. catappa, Calophyllum inophyllum, Cynometra ramiflora, Pandanus spp., Annona glabra, Salvadora persica, S. oleoides, Pongamia pinnata, Ricinus communis, Salicornia bigelovii, Xylocarpus granatum, X. mekongensis, X. moluccensis, Butea monosperma, Balanites roxburghii, Entada phaseoloides, Horsfieldia irya, Eruca sativa (cultivated), Sisymbrium irio and Lepidium sativum (cultivated) are of medicinal values [10, 29-30] and can be explored for commercial purposes. Many medicinal and aromatic plants such as Aloe vera, Asparagus racemosus, Adhatoda vasica, Cassia angustifolia, Catharanthus roseus, Citrullus colocynthis, Lepidium sativum, Ocimum sanctum, Plantago ovata, Glycyrrhiza glabra, Matricaria chamomilla, Cymbopogon flexuosus, C. martini and Vetiveria zizanioides are successfully cultivated with saline water (EC up to $10 \mathrm{dS} \mathrm{m}^{-1}$ ) irrigation [31-35]. Dagar and Singh [11] while exploring biodiversity of saline habitats including of coastal regions of India, listed about 400 salt-tolerant plants of medicinal value based on the uses reported in literature.

While exploring the ethno-botany and plant resources of Andaman-Nicobar Islands, Dagar and Dagar [36] and Dagarand Singh [37] reported several plant species utilized by the aborigines for medicinal purposes. Some common medicinal halophytes found in saline localities include Acanthus ilicifolius, A. volubilis, Achyranthes aspera, Acrostichum aureum (fern abundant behind mangroves in tidal zone), Adhatoda vasica, Aloe barbadensis, Barringtonia acutangula, B. racemosa, Caesalpinia bonduc, C. crista, Calophyllum inophyllum, Catharanthus roseus, Cerbera manghas, Citrullus colocynthis, Clerodendron inermie, Cressa cretica, Cycus rumphii (Gymnosperm), Cynometra ramiflora, Desmodium umbellatum, Heritieria fomes, H. littoralis, Hernandia peltata, Hibiscus tiliaceous, Ipoemoea pes-caprae (also ornamental and good sand binder), Manilcara littoralis, Macaranga peltata, Ochrosia oppositifolia (also used as fish poison), Pandanus spp, Pongamia pinnata, Ricinnus communis, Scaevola sericea, Scyphiphora hydrophyllacea, Sophora tomentosa, Tabernaemontana crispa, Tournefortia ovata, Thespesia populnea, Vigna marina, Withania somnifera and Xylocarpus granatum. Many of these have been domesticated for their high value products and more may be cultivated after getting their market assured. We are familiar that most of the mangroves are the good source of fuel wood and charcoal and are explored beyond repairs. In recent times, much attention is being given in using these potential resources for cultivating in saline habitats and also as salt-tolerant material for developing potential food crops.

\section{Landscape and Ornamental Plants}

Many attractive halophytes can be used as ornamental and landscape plants, especially in areas where water is scarce for irrigation. These may be trees, shrubs, succulents and semisucculents, biennial and perennial ground cover and lawn grasses. Some of them are reported to tolerate irrigation water with EC of 15 to almost $50 \mathrm{dS} \mathrm{m}^{-1}$ [38]. Plants such as Batis maritima, Conocarpus erectus, Eucalyptus sargentii, Melaleuca halmaturorum, species of Casuarina and Ficus; and the shrubs Mairreana sedifolia, Borrichea frutescens and Clerodendrum inerme are already being used as landscaping [14]. Aster tripolium, Crithmum maritimum, Eryngium maririmum, Inula crithmoides, Kalidium capsicum, Kochia scoparia, Suaeda vera, Ipomoea stolnifera, Limonium auriculaeursifolium, L. californicum, L. cordatum, L. cylindrifolium, L. ferulacium, $L$. hirsuticalyx, L. sinuatum, L. vulgare, L. spiculata, Limoniastrum monopetalum, Lotus creticus, L. cystisoides, Plantago crassifolia, Otanthus maritimus, Tamarix nilotica, T. amnicola, T. galica, T. africana, T. salina, T. tetragyna, Cistanche fistulosum, Atriplex halimus, Sesuvium portulacastrum, and Noronhia emerginata are some useful ornamental plants [15,39]. Some annual flowers such as Chrysanthemum indicum, Calandula officinalis, Matthiola incana and Matricaria chamomilla can be cultivated with saline water.

\section{Environmental Protection}

Most of the mangroves and their associates [30,40,24] play very important role in protecting the coastline and restoration of coastal ecosystem. Mangroves bear a net of aerial roots protecting the coastal area of their habitats from cyclonic tidal waves. They also provide life support system through food web to different organisms including coastal wild life. Animals such as saltwater crocodiles, turtles, water monitor lizards, snakes, wild pig, monkeys, deer, even tiger (in Sunderbans), several indigenous and migratory birds, mud skippers, molluscs, insects and crustaceans take shelter in mangrove ecosystem. Many species such as Aeluropus lagopoides, Clerodendrum inerme, Clitorea turnesia, Fimbristilis littoralis, Heliotropium curassavicum, Ipomoea pes-caprae, Launea sarmentosa, Sesuvium portulacastrum, Spinifex littoreus, Suaeda maritima, Zoysia matrella, etc. are found frequently along sandy beaches and protect sand from erosion. Dagar [10,23.41] the role of mangrove vegetation for coastal protection and livelihood security. Tree and grass species grown for sand stabilization in desert areas are dealt in detail by Dagar [42,43] and Dagar and Gupta [44].

\section{Environmental and Economical Sustainability of Biosaline Agriculture}

The success and long-term sustainability of any farming system based on halophytes will depend on continued efforts on selecting, domesticating and breeding halophytic crops $[45,46]$. As is evident from above account, there is already a considerable information available regarding potential species, which can contribute valuable and economic production. Moreover, halophytic germplasm may provide useful salt-tolerant genes for genetic engineering research 
and the development of stress tolerant crops [47], particularly in the scenario of climate change. The introduction of halophytes in farming systems will depend to large extent upon the socioeconomic needs and climate related adaptation compulsions. The environmental and economical sustainability of saline agriculture largely depends upon:

(i) Bio-reclamation (remediation) of Salt-affected soils using halophytic crops

(ii) Use of saline water for irrigation so that minimum damage is done to soil health, and

(iii) Sustainable and remunerative yield from saline agriculture

Saline agroforestry can also be a potential strategy for sustainable and assured crop production and reducing carbon dioxide in the atmosphere through carbon sequestration in Saltaffected and also waterlogged areas $[48,49]$. Since the halophytes can reduce the salt content of soil considerably over time [5]. Based on several studies conducted in Indian sub-continent and reported from time to time $[50,28,2,3]$, it can safely be concluded that tree based saline agriculture (biosaline agroforestry) is time tested, sustainable to climate related changes, and economically viable. Some of these examples have been discussed here.

\section{Agroforestry-based Agricultural Systems}

Conventional agriculture on highly salt-affected soils and also irrigating with water of high salinity is economically not viable because of low crop yields and physically removal of salts is expensive for most of the farmers [51]. However, saline agroforestry systems may be an alternative land use option for these soils. This is because some tree species are less susceptible to extreme salinity/ sodicity as compared to arable crops and these have the capability of removing salts and reclamation of these soils $[52,53,27]$. Some tree species such as Casuarina obesa, Eucalyptus camaldulensis and Tamarix articulata adapt to waterlogging conditions by developing root aeranchyma and adventitious (nodal) roots [54]. Though many biosaline agroforestry systems have been developed in South Asia and elsewhere in the world [55-60]. Only a few studies have evaluated the economic performance of such systems [61,62]. With respect to environmental performance of these studies emphasis has been given on amelioration of soil and organic carbon content in the soil [63-65], but has not studied other environmental factors, especially the balance of greenhouse gases in these systems. Recently, Wicke [62] explored the greenhouse gas balance and the economic performance (i.e. net present value (NPV) and production costs) of agroforestry and forestry systems on Salt-affected soils based on three case studies in South Asia.

The economic impact of trading carbon credits generated by biosaline agroforestry was also assessed as a potential additional source of income. The greenhouse gas balance showed carbon sequestration over the plantation lifetime of $24 \mathrm{Mg} \mathrm{CO}_{2}$-eq.. ha-1 in a rice Eucalyptus camaldulensis agroforestry system on moderately saline soils in coastal Bangladesh (case study 1), $6 \mathrm{Mg} \mathrm{CO}_{2}$-eq. ha-1 in the rice wheat Eucalyptus tereticornis agroforestry system (trees on boundary only) on sodic/saline sodic soils in Haryana state, India (case study 2), and $96 \mathrm{Mg} \mathrm{CO}_{2}$-eq. ha ${ }^{-1}$ in the compact tree (Acacia nilotica) plantation on saline-sodic soils in Punjab province of Pakistan. The NPV at a discount rate of $10 \%$ was reported to be

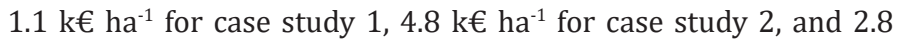
$\mathrm{k} € \mathrm{ha}^{-1}$ for case study 3 . According to them, carbon sequestration translates into economic values that increase the NPV by $1-12 \%$ in case study $1,0.1-1 \%$ in case study 2 , and $2-24 \%$ in case study 3 depending on the carbon credit price (1-15 € $\mathrm{Mg} \mathrm{CO}_{2}$-eq). The analysis of the three cases indicated that the economic performance strongly depends on the type and severity of salt affectedness (which affect the type and setup of the agroforestry system, the tree species and the biomass yield), markets for wood products, possibility of trading carbon credits, and discount rate.

Recent research efforts have greatly improved the understanding of biology and management of forestry plantations on saline environments. By adopting reclamation technologies growing halophytes, the salt-affected lands can be productively used for arable agriculture after some time. Worldwide experiences suggest that though the human induced salinity problems can develop rapidly but the hydrological and engineering solutions (through sub-surface drainage) are very expensive. Thus, despite the availability of technical knows how, the rehabilitation of the Salt-affected land is progressing at a very slow pace. Moreover, implementation of these solutions is also constrained due to socioeconomic and political considerations. Therefore, agroforestry based technology is considered effective and cheap alternative solution, hence, agroforestry systems are now considered as viable alternatives. Though the salinity and waterlogging stresses can be hostile for the woody tree species, these are known to tolerate these stresses better than the annual arable crop species. Therefore, the existing information is collated here in brief on site specific agroforestry systems and appropriate afforestation technologies for saline and waterlogged environments of the varied agro climatic situations.

\section{Agroforestry in Sodic/Alkali Lands}

Though the records of plantations on alkali soils are available from 1874 [66-68], but in India systematic experimentations were initiated only after 1980s after developing pit-auger-hole technique for piercing the hard kankar (calcite) pan present in sub-surface layer of highly sodic soils with $\mathrm{pH}$ exceeding 10 $[69,70,53]$. Based on the performance of tree saplings in alkali soils $(\mathrm{pH}>9$ ), relative tolerance of some species was in the order: Prosopis juliflora $>$ Acacia nilotica $>$ Haplophragma adenophyllum $>$ Albizia lebbeck > Syzygium cuminii [71]. In another study, Dagar [56] evaluated several tree species and found that Prosopis juliflora, Acacia nilotica and Tamarix articulata recorded good growth and were economically suitable in highly alkali $(\mathrm{pH} 10.1-10.6)$ soil. 
After 10 years of energy plantation, Singh, et al. [72] observed the Acacia nilotica (50.8 $\left.\mathrm{Mg} \mathrm{ha}^{-1}\right)$, Casuarina equisetifolia (42.1 $\left.\mathrm{Mg} \mathrm{ha}^{-1}\right)$ maximum biomass by Prosopis juliflora (56.5 $\mathrm{Mg} \mathrm{ha}^{-1}$ ) followed by and Tamarix articulata with $41.6 \mathrm{Mg} \mathrm{ha}^{-1}$.

Table 2: Change in soil properties as influenced by trees after 12 years of growth on highly sodic soil [133].

\begin{tabular}{|c|c|c|c|c|}
\hline Tree specie & pHs & Organic C $\left(\mathrm{g} \mathrm{kg}^{-1}\right)$ & Available P $\left(\mathrm{kg} \mathrm{ha}^{-1}\right)$ & Available K (kg ha-1) \\
\hline Acacia nilotica & 8.5 & 8.5 & 14 & 165 \\
\hline Acacia catechu & 8.3 & 6.7 & 20 & 225 \\
\hline Albizia procera & 8.3 & 4.5 & 9 & 125 \\
\hline Azadirachta indica & 8.5 & 7.5 & 12 & 240 \\
\hline Cassia siamea & 8.3 & 8.5 & 23 & 165 \\
\hline Dalbergia sissoo & 8.6 & 6.1 & 14 & 210 \\
\hline Eucalyptus tereticornis & 7.2 & 5.3 & 9 & 140 \\
\hline Leucaena leucocephala & 7.8 & 5.6 & 11 & 210 \\
\hline Morus alba & 8.4 & 6.1 & 14 & 210 \\
\hline Terminalia arjuna & 8.7 & 5.8 & 11 & 175 \\
\hline Initial soil & $>10.0$ & 1.2 & 6 & 85 \\
\hline
\end{tabular}

Tree plantations in sodic soil can ameliorate the soil (Table 2) within 10-12 years of growth to the extent that arable crops can be grown after their harvest. This process of amelioration can be hastened if we raise trees in silvo-pastoral mode [53]. Data of longterm growth of trees (20 years) showed that there is only marginal improvement in soil during next 10 years of growth, therefore, to get arable crops from sodic soils, trees may be harvested after 10-12 years of growth.The sodic lands are very poor in forage production under open grazing, but when brought under judicious management after protecting from grazing these could be explored successfully for sustainable fodder and fuel wood production. Grasses such as Leptochloa fusca, Brachiaria mutica, Chloris gayana, Panicum maximum, P. antidotale and Panicum laevifolium were found most promising and successful for these soils and can constitute viable silvo-pastoral system. L. fusca could be adjudged the most promising grass for high sodicity $(\mathrm{pH}>10)$, saline and waterlogged soils. This also fixes atmospheric nitrogen and absorbs high quantity of salt, hence helps in quick reclamation of these soils. On an average this grass produced $16-18 \mathrm{Mg} \mathrm{ha}^{-1}$ dry biomass along with P. juliflora and Acacia nilotica trees [53].

Based on the evaluation of $>60$ species (through series of experimentation on sodic soils in Indian sub-continent), it could be concluded that Prosopis juliflora was the best candidate for high pH (> 10) sodic soils followed by Tamarix articulata and Acacia nilotica. Species such as Eucalyptus tereticornis, Terminalia arjuna, Salvadora oleoides, Cordia rothii and fruit trees such as Carissa carandas, Emblica officinalis, Syzygium cuminii and Psidium guajava could be grown with great success on moderate alkali $(\mathrm{pH}$ $<9.5$ ) soil. Wider spaced (row to row 4-5m, plant to plant $4 \mathrm{~m}$ ) tree plantation was accommodated with arable crops in the interspaces. Egyptian clover (Trifolium alexandrinum), wheat, onion (Allium sativum) and garlic (Allium cepa) were grown successfully for three years with fruit trees Carissa carandas, Punica granatum, Emblica officinalis, Psidium guajava, Syzygium cuminii and Ziziphus mauritiana. Understory intercrops such as fodder grass Leptochloa fusca, wheat for grain, and onion and garlic for bulbs could be cultivated profitably [73]. To avoid water stagnation problem in alkali soils during rainy season, Dagar [56] developed raised and sunken bed technology growing fruit trees on bunds and above mentioned arable and forage crops in sunken beds successfully. Another advantage of this technique is that moisture is conserved in sunken beds during lean period.

The Salt-affected black soils (saline/sodic vertisols) also can successfully be cultivated with forest and fruit trees. P. juliflora, Salvadora persica and Azadirachta indica are the most successful tree species for these soils. Among fruit trees, gooseberry (Emblica officinalis), ber (Ziziyphus mauritiana) and sapota (Achras zapota) can be grown successfully and are highly profitable on sodic vertisols (ESP 25-60). Following raised and sunken bed technique, fruit trees like pomegranate (Punica granatum), Jamun (Syzygium cuminii) and goose berry (Emblica officinalis) can successfully be grown on raised bunds with rain fed rice during rainy season and suitable winter crops in residual moisture in sunken beds. Among grasses, Aeluropus lagopoides, L. fusca, B. mutica, C.gayana, C. barbata, Dichanthium annulatum, D. caricosum, Bothriochloa pertusa and species of Eragrostis, Sporobolus and Panicum are among the most suitable for silvo-pastoral system on sodic vertisols. In addition to their economic values, L. fusca, B. mutica and Vetiver zizanioides assimilated high amounts of sodium from soils. During three years, these grasses removed $144.8,200.0$ and $63.5 \mathrm{~kg} \mathrm{ha}^{-1}$ sodium from soil, respectively [74].

Aromatic grasses such as palmarosa (Cymbopogon martini) and lemon grass (C. flexuosus) tolerate moderate sodicity $(\mathrm{pH}$ 9.2) while vetiver (Vetiveria zizanioides) withstands both high $\mathrm{pH}$ and water stagnation [73]. Medicinal psyllium (Plantago ovata) produced 1.47-1.58 $\mathrm{Mg} \mathrm{ha}^{-1}$ grain (including husk) at $\mathrm{pH} 9.2$ and 1.03 to $1.12 \mathrm{Mg} \mathrm{ha}^{-1}$ at $\mathrm{pH} 9.6$ showing its potential for cultivation 
on moderate alkali soil [75]. Matricaria chamomile, Catharanthus roseus and Chrysanthemum indicum are other interesting medicinal and flower yielding plants for moderate alkali soil [76]. All these crops can be blended suitably as understory inter-crops in agroforesty systems with both forest and fruit trees grown in wider spaces. Mulhatti (Glycyrrhiza glabra), a leguminous medicinal crop was found quite remunerative in moderate alkali soil (up to $\mathrm{pH}$ 9.6). Besides 2.4-6.2 $\mathrm{Mg} \mathrm{ha}^{-1}$ forage per annum from aerial branches after harvesting during winter, a root biomass (medicinal and commercial) of 6.0-7.9 $\mathrm{Mg} \mathrm{ha}^{-1}$ could be obtained after three years of growth, Dagar [77] fetching INR 6-8 lakhs ha-1 i.e. 2.0-2.6 lakhs ha ${ }^{-1}$ ( 1 lakh=100 thousand; $\sim 63$ INR=1\$ in 2015) per annum and the soil was ameliorated in terms of reduction in $\mathrm{pH}$ and ESP and increase in organic carbon significantly.

\section{Agroforestry in Saline and Waterlogged Soils}

It has been observed that many people to avoid stagnation of water plant trees on bunds in saline soils. It has been found that most of the salt deposit in these bunds and there is huge mortality. Therefore, technique of furrow planting was developed and found successful in waterlogged saline soils $[78,23]$. Based on long term experiments, it was found that energy plantation of Prosopis juliflora, Tamarix articulata, T. traupii, Acacia farnesiana, Parkinsonia aculeata and Salvadora persica could be raised successfully on saline soils having ECe up to 30-40 dS $\mathrm{m}^{-1}$. Likewise, A. nilotica, A. tortilis, A. pennatula, Casuarina glauca, C. obesa, C. equisetifolia, Callistemon lanceolatus, Eucalyptus camaldulensis, Feronia limonia, Leucaena leucocephala and Ziziphus mauritiana are suitable for soils with ECe 10-20 dS m ${ }^{-1}$. (For more details, consult Tomar [78] and Dagar [23].

Dagar Yadav [4] reviewed the results of several experiments and reported that among grasses, Aeluropus lagopoides, Leptochloa fusca, Sporobolus helvolus, Cynodon dactylon, Brachiaria ramosa, Dactyloctenium aegyptium, Dichanthium annulatum, D. caricosum, Panicum maximum, Digitaria ciliaris and Eragrostis sp. are among most suitable species for silvo-pastoral systems on saline conditions in Indian sub continent. Species such as Atriplex amnicola, A. lentiformis, A. undulata, Acacia cambage and Leptachloa fusca can produce potential forage biomass on saline soils of ECe 20-30 $\mathrm{dS} \mathrm{m}^{-1}$. While many others such as Sesbania aculeata, Leucaena leucocephala, Medicago sativa, Lolium multiflorum, Echinochloa colonum, and species of Panicum tolerate the salinity up to EC 10$12 \mathrm{dS} \mathrm{m}^{-1}$. Samphires (Halosarcia pergranulata, H. lepidosperma and $H$. indica subsp. bideris) and blue bush (Maireana brevifolia) are highly salt-tolerant succulent perennial shrubs, which could be grown on waterlogged salt land pastures in Australia. $H$. pergranulata contains about $14 \%$ crude protein on oven dry basis and is better suited to sheep grazing [54]. Some of these species have been successfully introduced elsewhere also.

In tidal zones along coast, mangroves can be explored for economic use in saline areas of coastal regions. Some common mangrove and associate species include Acanthus ilicifolius, A. volubilis, Aegialitis rotundifolia, Aegiceras corniculatum, Avicennia marina, A. officinalis, Bruguera gymnorrhiza, B. parviflora, B. cylindrica, Ceriops tagal, C. decandra, Cynometra ramiflora, C. iripa, Excoecaria agallocha, Heritiera fomes, H. littoralis, Kandelia candel, Lumnitzera racemosa, (L. littoris in Andamans only), Nypa fruticans, Phoenix paludosa, Rhizophora apiculata, R. mucronata, R. stylosa, Scyphiphora hydrophyllacea, Sonneratia alba, S. apetala, S. caseolaris, S. ovata, Xylocarpus gangeticus, X. granatum. Other associated common salt-tolerant species include Acrostichum aureum, Barringtonia asiatica, B. racemosa, Caesalpinia bonduc, C. crista, Calophyllum inophyllum, Casuarina equisetifolia, Cerbera floribunda, Erythrina indica, E. variegata, Hernandia peltata, Hibiscus tiliaceous, Intsia bijuga, Licuala spinosa, Manilkara littoralis, Morinda citrifolia, Ochrosia oppositifolia, Pongamia pinnata, Pandanus spp., Scaevola taccada, Tabernamontana crispa, Terminalia catappa, Thespesia populnea, Tournefortia ovata and Vitex negundo. These also provide an important habitat for young stages of commercially important fish and prawns, and as breeding grounds for fish, shellfish and turtles and home for variety of wild life $[79,80]$. In scenario of climate change and sea level rise rehabilitation of mangrove areas planting mangrove and associate species will not only save the coastal areas from disasters like cyclones and tsunamis but it will sequester huge amount of carbon and protect wild coastal marine life.

Introduction of canal irrigation in arid and semi-arid regions without provision of adequate drainage caused rise in groundwater leading to waterlogging and secondary salinization. Installation of sub-surface drainage is essential to overcome the aforesaid twin problems; however, it is very costly and disposal of saline effluents has inherent environmental problems. Tree plantations for biodrainage, which is 'pumping of excess soil water by deep rooted plants using bioenergy', can be a viable alternative. Heuperman [81] observed that the plantations act like groundwater pumps (tube wells), pumping out water @ $34460 \mathrm{~m}^{3} \mathrm{yr}^{-1}$ or $3.93 \mathrm{~m}^{3} \mathrm{hr}^{-1}$ ha $^{-1}$ of plantation. Plantations in the Indira Gandhi Nahar Paryojana (IGNP) command in India, was observed to use water @ 3446 mm yr- ${ }^{1}$, which was about 1.4 Class A pan, without any significant increase in salinity of soils and groundwater.

There are many other evidences also which show that trees help in reducing salinity, lowering water table and checking seepage depending upon their salt tolerance [82]. Several plant species, from salt bush (Atriplex) to tall trees like species of Eucalyptus, Casuarina equisetifolia, C. glauca, Pongamia pinnata and Syzygium cuminii, are found suitable for this purpose. The main physiological feature of such vegetation is profuse transpiration whenever the root system meets ground water. Several tree species have been shown to survive and grow in waterlogged and saline soils and being used increasingly to utilize and rehabilitate salt-affected and waterlogged areas [83-85].

One of the most promising tree species used for biodrainage is Eucalyptus tereticornis (Mysure gum) which is widely distributed 
and fast growing under a wide range of climatic conditions. It grows straight with low shading effect and has luxurious water consumption excess soil moisture conditions. In waterlogged non-saline areas, it can be successfully grown by ridge planting. In saline waterlogged areas, sub-surface or furrow planting is more successful as compared to ridge method [78]. Area under Eucalyptus plantation has increased to 20 million ha in the world and its fast growth rate, favourable wood properties, and high carbon sequestration potential makes it a good option for biodrainage $[86,87]$.

Block plantation of E. tereticornis along IGNP area, effectively lowered the water table by $15.7 \mathrm{~m}$ over a period of six years [88]. Likewise, strip plantations at $1 \mathrm{~m} \times 1 \mathrm{~m}$ space on acre line lowered shallow saline water table by $0.85 \mathrm{~m}$ during a period of 3 years and $\sim 2 \mathrm{~m}$ after 5 years [89]. The average above and below ground oven dry biomass and carbon sequestration of $5 \frac{1}{2}$ years old 240 surviving trees strip plantation reached 24.0 and $8.6 \mathrm{Mg} \mathrm{ha}^{-1}$ and $15.5 \mathrm{Mg} \mathrm{ha}^{-1}$, respectively. The results of six years old cloned Eucalyptus plantation when raised in different spacings on acre line and as block plantations along canal produced $193 \mathrm{Mg} \mathrm{ha}^{-1}$ biomass as compared to $49.5 \mathrm{Mg} \mathrm{ha}^{-1}$ under $1 \mathrm{~m} \times 1 \mathrm{~m}$ space planting on acre line. These plantations could sequester 9.5 to $22.8 \mathrm{Mg} \mathrm{ha}^{-1}$ carbon in different spaces and $90.6 \mathrm{Mg} \mathrm{ha}^{-1}$ in block plantation after 6 years of plantation (Table 3). The plantations maintained the water table $<2 \mathrm{~m}$ throughout the growing season and thus helped farmers to cultivate both rice and wheat crops in time and yield was many fold as compared to those farmers who did not plant trees in their fields in the viscinity.

Table 3: Harvested dry biomass and carbon sequestration $\left(\mathrm{Mg} \mathrm{ha}^{-1}\right)$ in different parts of clonal Eucalyptus after 6 years of growth when grown on bunds with different spacing and as block plantation along canal. (Values in parenthesis are for carbon sequestered).

\begin{tabular}{|c|c|c|c|c|}
\hline Plant part & $1 \mathrm{~m} \times 1 \mathrm{~m} 300$ trees ha $^{-1 *}$ & $1 \mathrm{~m} \times 2 \mathrm{~m} 150$ trees ha- $1 *$ & $1 \mathrm{~m} \times 3 \mathrm{~m} 100$ trees ha ${ }^{-1 *}$ & Block $(2 \mathrm{~m} \times 4 \mathrm{~m}) 1250$ trees ha $^{-1 *}$ \\
\hline Timber (main bole) & $33.5(15.5)$ & $19.1(8.9)$ & $16.7(7.7)$ & $141.7(66.5)$ \\
\hline Twigs \& leaves & $2.6(1.2)$ & $1.5(0.8)$ & $1.3(0.4)$ & $9.8(4.5)$ \\
\hline Roots & $13.4(6.1)$ & $8.0(3.8)$ & $5.4(2.4)$ & $41.4(19.6)$ \\
\hline Total & $49.5(22.8)$ & $28.7(13.5)$ & $20.0(9.5)$ & $192.9(90.6)$ \\
\hline
\end{tabular}

Note: *Number of trees planted per ha (most of the trees survived after gap filling) Source: Dagar et al. [49]

\section{Agroforestry with Application of Saline Irrigation}

In most of the dry ecologies due to scarcity of good quality water sustaining agriculture is major problem. The decrease of water availability in developing countries is more serious threat due to burgeoning population pressure and availability of limited arable land for cultivation. An innovative strategy for enhancing land and water availability is the use of salt-affected land and poorquality water to develop saline agriculture as a practice. In arid and semiarid regions saline aquifers are available in plenty while in coastal areas use of sea water is inevitable. The strategy is not new, as, for example, the use of sea water for crop production in coastal deserts has already been suggested in the last four decades [1] using potential halophytes as crops. But in arid and semi-arid conditions, the use of saline water for irrigation has been limited.

Tomar, Minhas [90], Tomar [91,92], Dagar [93,94] and Dagar [23] have developed technologies for successful establishment and better growth of forest and fruit trees, grasses, arable and non conventional medicinal and aromatic crops in agroforestry system using saline groundwater for irrigation. Several salt-tolerant tree species (planted in furrows used for irrigation in a space of $2 \mathrm{~m} \times 2 \mathrm{~m}$ ) like Tamarix articulata, Azadirachta indica, Acacia nilotica, A. tortilis, A. farnesiana, A. ampliceps, Cordia rothii, Cassia siamea, Eucalyptus tereticornis, Feronia limonia, Prosopis juliflora, Pithecellobium dulce, Salvadora persica, S. oleoides and Ziziphus mauritiana could be established using sub-surface planting and furrow irrigation technique on degraded calcareous soil using saline water up to
EC of 10-12 dS m$~^{-1}$. Alternate rows were harvested after 5 years; thereafter, alternate trees were harvested after 8 years to give space for growth.

After 20 years of growth trees of many of the species produced good biomass. For example, T. articulata, A. nilotica, A. tortilis, P. juliflora, E. teriticornis, A. indica and C. siamia produced 392, $230,185,154,145,123$, and $122 \mathrm{Mg} \mathrm{ha}^{-1}$ above ground biomass, respectively and A. nilotica, Feronia limonia, A. tortilis, G. ulmifolia, T. articulata and $A$. indica were among the most efficient in improving SOC (Figure 1) to > $5.5 \mathrm{~g} \mathrm{~kg}^{-1}$ (Dagar, et al. 2018, unpublished). Among tested forage grasses, Tomar [95] cultivated using saline water (EC up to $10 \mathrm{dS} \mathrm{m}^{-1}$ ) which also could be grown with trees as silvo-pastoral system include Panicum laevifolium which produced maximum annual forage dry biomass (16.9 $\mathrm{Mg} \mathrm{ha}^{-1}$ ) followed by P. maximum (13.7 $\mathrm{Mg} \mathrm{ha}^{-1}$ ). Among other species growing naturally, Cenchrus ciliaris, C. setigerus, Sporobolus spp., Panicum antidotale, Dichanthium annulatum, D. caricosum, Cynodon dactylon, Digitaria ciliaris, $D$. decumbense, Dactyloctenium aegyptium and D. sindicum are prominent. Sufficient forage can be made available from these perennial grasses with one or two irrigations with saline water (EC up to $12 \mathrm{dS} \mathrm{m}^{-1}$ ) even in the lean period when people are forced to lead nomadic life along with their herds of cattle. One irrigation with saline water during summer improved forage yield of these grasses to 3-5 $\mathrm{Mg} \mathrm{ha}^{-1}$. Such use of saline groundwater is applicable for large grazing areas in dry ecologies having saline aquifers which otherwise remain barren. Rye grass (Lolium sp), oat (Avena sativa) 
and sorghum (Sorghum sp), producing satisfactory green forage of good proximate quality even with conjunctive irrigations of saline drainage effluents and fresh water [96]; these can also be grown successfully with trees.

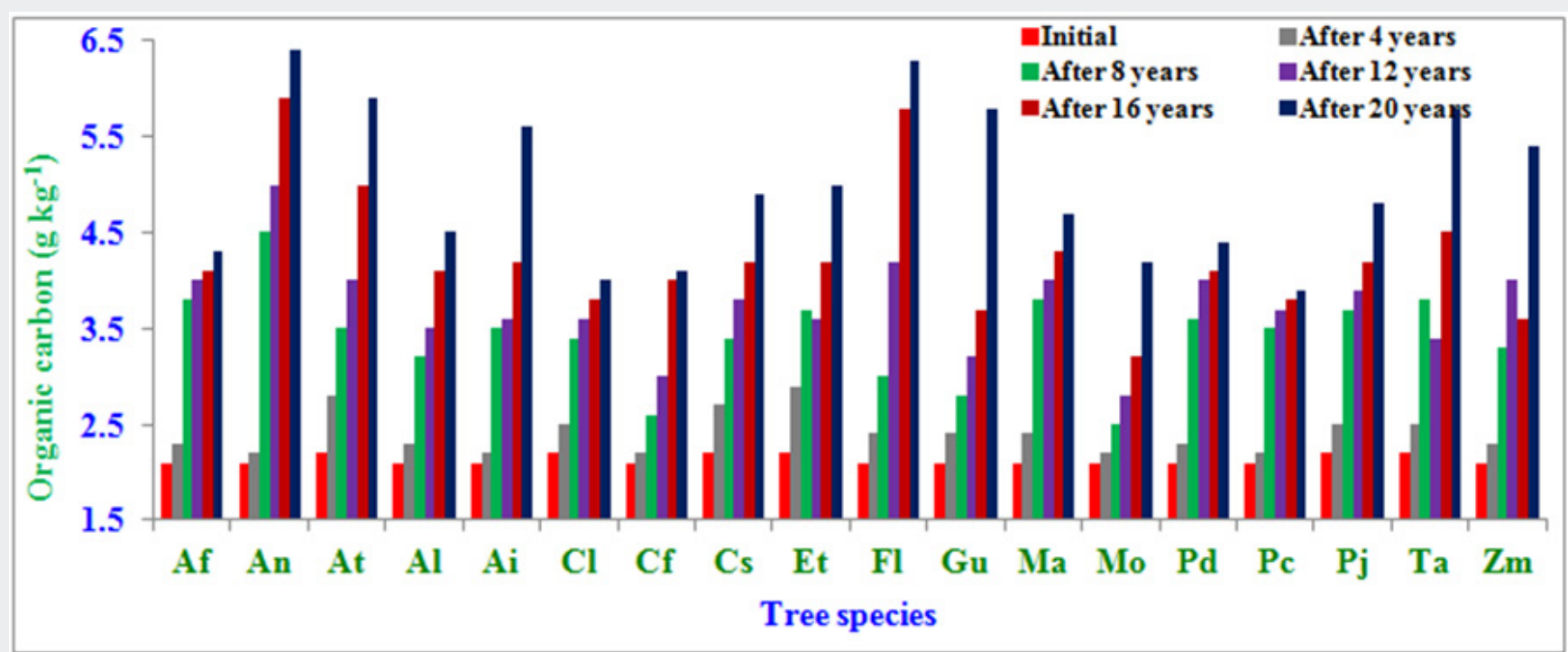

Figure 1: Development of organic carbon in soil under different tree species (established with saline water) at different interval of time. Depictions: $\mathrm{Af}=$ Acacia farnesiana, $\mathrm{An}=$ Acacia nilotica, $\mathrm{At}=\mathrm{A}$. tortilis, $\mathrm{Ai}=\mathrm{Azadirachta}$ indica, $\mathrm{Cs}=\mathrm{Cassia}$ siamea, $\mathrm{C}=\mathrm{C}$. javanica, $\mathrm{Cf}=\mathrm{C}$. fistula, $\mathrm{Cl}=$ Callistemon lanceolatus, $\mathrm{Et}=$ Eucaluptus tereticornis, $\mathrm{Gu}=$ Guazuma ulmifolia, $\mathrm{Ma}=$ Melia azedarach, $\mathrm{Pd}=$ Pithecellobium dulce, $\mathrm{Pj}=$ Prosopis juliflora, Ta= Tamarix articulata, $\mathrm{Zm}=$ Ziziphus mauritiana (Source: Based on Dagar, et al. 2018, unpublished).

Among fruit trees, Carissa carandas, Emblica officinalis, Feronia limonia, Ziziphus mauritiana and Aegle marmelos were found promising. In the inter-spaces, crops such as pearl millet (Pennisetum typhoides), cluster bean (Cyamopsis tetragonoloba) and sesame (Sesamum indicum) during kharif and barley (Hordium vulgare) and mustard (Brassica juncea) during rabi were found highly profitable [77]. Medicinal crops such as psyllium (Plantago ovata), Aloe vera, and Withania somnifera may find place as intercrops as these are found doing well in partial shade. Among other non-conventional crops, vasaka (Adhatoda vasica), castor (Ricinus communis), Dill (Anethum graveolens), tara-mira (Eruca sativa), periwinkle (Catharanthus roseus), vetiver (Vetiveria zizanioides) and lemon grass (Cymbopogon flexuosus) could be cultivated successfully. Their agronomic practices irrigating with saline water have been standardized [97].
Cassia senna and Lepidium sativum could also be cultivated successfully irrigating with saline water of EC $8 \mathrm{dS} \mathrm{m}^{-1}$. All these high value crops can successfully be grown as inter crops with forest or fruit trees at least during initial years of establishment [82]. Dagar [23] and Gururaja Rao [98] advocated that highly saline black soils, both in irrigation commands and coastal areas, can successfully be brought under economic cultivation of halophytes, which can be cultivated both on saline lands and irrigating with saline water. Among trees, Acacia nilotica, Azadirachta indica, Salvadora persica, Casuarina equesitifolia, and Prosopis juliflora are found most successful. Fruit trees such as pomegranate (Punica granatum), Carissa carandas, Goose berry (Emblica officinalis), and Ziziphus mauritiana can be cultivated. Grasses such as Distichlis spicata, Leptochloa fusca and Paspalum scrobiculatum have performed very well in these soils irrigating with saline water (Table 4).

Table 4: Total dry matter production of three grass species irrigated with moderately saline and highly saline water.

\begin{tabular}{|c|c|c|}
\hline \multirow{2}{*}{ Grass species } & \multicolumn{2}{|c|}{${\left.\text { Total yield (kg ha }{ }^{-1}\right)^{*}}^{2}$} \\
\cline { 2 - 3 } & Moderate salinity & $817^{\mathrm{b}}$ \\
\hline Distichlis spicata & $1444^{\mathrm{a}}$ & $256^{\mathrm{d}}$ \\
\hline Leptochloa fusca & $215^{\mathrm{d}}$ & $558^{\mathrm{c}}$ \\
\hline Paspalum scrobiculatum & $941^{\mathrm{b}}$ & 203 \\
\hline LSD $(\mathrm{p} \leq 0.05)$ & & \\
\hline
\end{tabular}

Note: *Treatment means with the same superscript are not significantly different $(\mathrm{p} \leq 0.05)$. 
Other grasses such as Aeluropus lagopoides, Dichanthium annulatum, species of Eragrostis and Panicum perform very well. Salvadora persica has been found economically viable species in these soils and can withstand very high salinity. Irrigation with saline water at flowering stage has been found very useful. The plant starts bearing during second year of growth and during $4^{\text {th }}$ and $5^{\text {th }}$ year it could produce about $1800 \mathrm{~kg}$ seed per ha with 40 $50 \%$ seed oil and it gives economic yield when irrigated water of EC up to $55 \mathrm{dS} \mathrm{m}^{-1}$ (Table 5). This species giving economic yield at high salinity also provides eco-restoration and thus showing its niche for highly saline black soils.

Table 5: Seed production and economic returns of Salvadora plantation on highly s saline black soils $\left(\mathrm{ECe}>55 \mathrm{dS} \mathrm{m}^{-1}\right)$.

\begin{tabular}{|c|c|c|c|c|}
\hline Year & Seed yield $\left(\mathbf{k g ~ h a}^{-1}\right)$ & \multicolumn{2}{|c|}{ Returns (INR ha-1 } & Cost/Benefit ratio \\
\hline & & Gross & Net & Nil \\
\hline $1^{\text {st }}$ year & Nil & Nil & 365 & 10.03 \\
\hline $2^{\text {nd }}$ year & 725 & 3625 & 4340 & 0.13 \\
\hline $3^{\text {rd }}$ year & 978 & 4890 & 7250 & 0.09 \\
\hline $4^{\text {th }}$ year & 1580 & 7900 & 8440 & 0.09 \\
\hline $5^{\text {th }}$ year & 1838 & 9190 & & Nil \\
\hline
\end{tabular}

Source: Gururaja Rao, et al. [76]

Conjunctive use of saline water with stored surface/canal water either in mixing or cyclic mode forms is another option in these soils. Apart from halophytes, industrially important crops like dill, safflower, and mustard and cash crops like cotton can also be cultivated with saline irrigation in vertisols. In addition, the use of treated effluents from fertilizer and petro chemical industries for irrigation of oilseed crops, forages, flowering plants and bio-fuel species such as Jatropha curcas has been found quite remunerative in water scarce areas. Among other important crops species include castor (Ricinus communis), mustard (Brassica campestris), Tara-Mira (Eruca sativa), dill (Anethum graveolens), carum (Trachyspermum ammi), coriander (Coriandrum sativum), and fenugreek (Trigonella foenum graceum) are suitable for water-scarce areas.

Many of the groundwaters in arid and semiarid regions also test high in residual alkalinity/sodicity. These waters contain high concentration of dissolved carbonates and bicarbonates of sodium, and carbonates $>$ chloride and sulphates, and high proportion of $\mathrm{Na}+$ with respect to $\mathrm{Ca}^{+2}+\mathrm{Mg}^{+2}$. The soluble $\mathrm{Na}$ percentage is generally $>75$ and the ratio of divalent cations to total cations is $<25$ for sodic waters. The alkalinity of water is expressed as sum of cations minus sum of anions other than carbonates. Residual alkalinity is expressed as:

$$
\left[\mathrm{HCO}_{3}-\mathrm{CO}_{3}{ }^{-2}\right]-\left[\mathrm{Ca}^{+2}+\mathrm{Mg}^{+2}\right]
$$

Determines the potential of irrigation water to create alkalinity hazard in the soil. This is expressed as residual sodium carbonate (RSC), used as an index of water suitability for irrigation of crops. In general, waters having high RSC test low in EC; some waters termed as saline-sodic test high in RSC, SAR and EC. Waters having $\mathrm{RSC}<2.5,2.5-5.0$, and $>5 \mathrm{meq} \mathrm{L}^{-1}$ are considered safe, marginal, and unsafe, respectively. Sodium Adsorption Ratio (SAR) is expressed as:

$$
[\mathrm{SAR}=(\mathrm{Na}) / \sqrt{ }(\mathrm{Ca}+\mathrm{Mg}) / 2]
$$

Choudhary (2014) has reviewed the work done in sodic water irrigation management. Application of gypsum to soil and passing the sodic water through irrigation channel have been reported to be effective means. Use of organic materials, fertility management and conjunctive use of poor and good quality (when available) waters are also found useful in reducing the effect of alkalinity. The selection of suitable crops which can absorb more sodium is also important while using these waters for irrigation. The agroforestry systems, which are suitable for (as discussed above) are also suitable for using alkali water for irrigation.

\section{Land-Reshaping Techniques for Coastal Waterlogged Saline Areas}

Salinity and inundation are inherent problems in coastal areas. Efforts have been made to develop land-shaping techniques for improving drainage, rain water harvesting, salinity reduction and cultivation of plantations and vegetable crops on dykes and fish for livelihood and environmental security [99-101]. These were tested on $\sim 400$ ha degraded land in Sundarbans region of Ganges delta and tsunami affected areas in Andaman and Nicobar Islands. The soil in the study area was highly saline (ECe up to $18 \mathrm{dS} \mathrm{m}^{-1}$ ) and water salinity (EC up to $22 \mathrm{dS} \mathrm{m}^{-1}$ ) that limits the choice and options of growing crops in the area. The land shaping technologies tested on farmers' fields included deep furrow and high ridge cultivation, shallow furrow and medium ridge cultivation, farm ponds, and paddy cum fish culture.

For details see Burman, et al. [100]. For island conditions, Velmurugan [24] have reported several socially and economically viable farming and agroforestry systems. Mangrove-based integrated farming systems towards sea-front having aquaculture as predominant component are interesting features. The system is environment friendly and highly economical. Andaman and Nicobar Islands, being rich in biodiversity, are the veritable treasure house of valuable medicinal, aromatic and dye herbs, trees and shrubs which can be produced organically. There is also good scope for the production of tropical fruits like mangosteen (Garcinia indica, G. cowa), mango (Mangifera indica), guava (Psidium guajva), Sapota (Achras zapota), custard apple (Annona squamosa), pine 
apple (Ananas comosus), durian (Durio zibethinus), dragon fruit (Hylocereus undatus), Rambutan (Nephelium lappaceum), jack fruit (Artocarpus spp), grapefruit (Citrus paradisi) and longan (Euphoria longan) which have high export potential. Besides, poultry, pig and cattle can be integrated with the crop components for efficient resource recycling and provide stability to farm income.

Some of the suitable multipurpose forest and fruit trees employed in agroforestry of islands include Acacia auriculaeformis,

Table 6: Suitable trees and shrubs for coastal saline sites.
Achras zapota, Anacardium occidentale, Bixa orellana, Borassus flabellifer, Calophyllum inophullum, Casuarina equisetifolia, Cocos nucifera, Erythrina indica, Ficus spp, Garcinia cowa, Hibiscus tiliaceus, Moringa oleifera, Musa paradisiaca, Trema tomentosa, Morinda citrifolia, Pandanus spp, Terminalia catappa, Pongamia pinnata, Ceiba pentendra, Gliricidia sepium, and Mangifera indica. For more details see Dagar [27]. Many of these species are salttolerant (Table 6).

\begin{tabular}{|c|c|}
\hline Strees condition & Suitable trees/ shrubs \\
\hline Very high salinity $\left(\mathrm{ECe}>35 \mathrm{dS} \mathrm{m}^{-1}\right)$ & $\begin{array}{l}\text { All mangrove species, associates e.g. Hibiscus tiliaceous, Salvadora persica, Suaeda spp, Arthrocnemum indicum, } \\
\text { Barringtonia asiatica, Manilkara littoralis, Morinda citrifolia, Calodendron inerme, Atriplex spp, Pandanus spp, etc }\end{array}$ \\
\hline $\begin{array}{l}\text { High salt-tolerant (ECe } 25-35 \mathrm{dS} \\
\qquad \mathrm{m}^{-1} \text { ) }\end{array}$ & $\begin{array}{l}\text { Casuarina equisetifolia, C. glauca,, Pongamia pinnata, Terminalia catappa, Calophyllum inophyllum, Ficus retusa, } \\
\text { Thespesia populnea, Anacardium occidentale, Clerodendron inerme, Acacia ampleceps and Cocos nucifera (on } \\
\text { specific sites) }\end{array}$ \\
\hline Tolerant (ECe 15-25 dS m-1) & $\begin{array}{c}\text { Acacia auriculaeformis, Achras zapota, Bixa orellana, Borassus flabellifer, Leucaena leucocephala, Albizia spp, Areca } \\
\text { catechu, Desmodium umbellatum, etc }\end{array}$ \\
\hline
\end{tabular}

\section{Seaweed Cultivation and Aquaculture Keeping Mangroves Intact in Coastal Areas}

Historically, coastal people have relied on seaweeds for food, minerals, medicine, insulation, fertilizer and fodder. Seaweed farming is the practice of cultivating and harvesting seaweed which is largely carried out as a diversification activity in mariculture. Many of the rocky beaches, mudflats, estuaries, coral reefs and lagoons provide ideal habitats for the growth of seaweeds. Seaweeds refer to any large marine benthic algae that are multicellular, macrothallic, and thus differentiated from most algae that are of microscopic size. They form an important renewable resource in the marine environment as evidenced from its annual production of about 7.0 - 8.0 million Mg of wet seaweed along the coastal regions of the world [102].

Seaweeds belonging to different genera are mainly used for edible and industrial purposes all over the world. In all, 271 genera and 1153 species of marine algae, including forms and varieties have been enumerated from the Indian waters by Krishnamurthy [103]. But, India presently harvests only about $2.5 \%$ of macro algae annually compared to a potential harvest of 870 thousand $\mathrm{Mg}$, thus lot of scope for harnessing the unutilized seaweed potential. The edible seaweed are algae that can be eaten and used in the preparation of food that belong to one of several groups of multicellular algae viz., red algae, green algae, and brown algae. Alternatively seaweeds are also harvested or cultivated for the industrial extraction of alginate, agar and carrageenan substances collectively known as hydrocolloids or phycocolloids. Hydrocolloids have attained commercial significance, especially in food production as food additives. The food industry exploits the gelling, water retention, emulsifying and other physical properties of these hydrocolloids. In India seaweeds are used as raw materials for the production of agar, aliginate and liquid seaweed fertilizers [104]. The sources of such materials and their cultivation methods are presented in Table 7.
In Lakshadweep, the estimated potential (fresh weight) is reported ranging from 4955 to $10,077 \mathrm{Mg}$ within an average value of $7519 \mathrm{Mg}$ while the Andaman and Nicobar Islands have been partly surveyed by Central Marine Fisheries Research Institute (CMFRI), Cochin and the highest standing crop of 19,111 $\mathrm{Mg}$ (fresh weight) was estimated for an area of $40 \mathrm{~km}^{2}$ in South Andaman. The total potential of the islands stands at $33363 \mathrm{Mg}$ but the level of exploitation is negligible due to policy issues and infrastructural inadequacy [24]. Among them Green algae followed by Red algae constitute the major species composition? Recently, natural incidence of Kappaphycus alvarezii has been reported from Andaman Islands. Ecological studies have been undertaken regarding the cultivation of the species and no adverse effects to the ecosystem by the species have been reported. Therefore, large scale cultivation of Kappaphycus alvarezii can be undertaken in these Islands.

The red seaweed Kappaphycus alvarezii syn. Euclheuma cottonii, is the major source of carrageenan, a hydrocolloid used as thickening and stabilizing agent in food, cosmetics, pharmaceuticals etc. The current annual world production of $K$. alvarezii is about $200 \mathrm{~K} \mathrm{Mg}$ and its value added product carrageenan is about $50000 \mathrm{Mg} \mathrm{yr}^{-1}$ [105]. In India, commercial faming of K. alvarezii was commenced in 2001 in Tamil Nadu. While fish catching is diminishing day by day and income is not predictable, therefore, $K$. alvarezii farming has become real alternative to the coastal people. Today, seaweeds are a multibillion dollar industry worldwide, providing food, fertilizers, nutritional supplements and valuable phycocolloids like agar, carrageenan and alginate. Although wild harvest supports a significant portion of seaweed industry, there is an ever increasing amount of seaweed production from aquaculture to meet the current demand. Seaweed aquaculture makes up a significant portion of organisms cultured worldwide ( $\sim 19$ million metric tons) with a value of $\sim \mathrm{US} \$ 5.65$ billion [105]. Aquaculture production is dominated by kelps (Saccharina japonica and Undaria pinnatifida), 
tropical red algal species (Kappaphycus and Eucheuma), nori (including Porphyra and Pyropia species) and the red algal agarophyte species known as Gracilaria.

The average monthly income of a cultivator ranges from INR 15000 to 30000 based on his efforts and volume of cultivation area. Extract obtained from fresh form of $K$. alvarezii is rich source of potassium with other micro and macronutrients. It has also naturally occurring growth hormones and amino acids and can improve crop yields of a variety of crops anywhere from 15 to $40 \%$
[105]. This provides a first ever opportunity to the farmers to have access to organic growth boosters at an affordable price in India. Most of the peninsular India is surrounding by sea, hence must be explored economically. Another interesting area is aquaculture keeping mangroves intact. Mangroves and corals are the base of food chain in marine ecosystem and are useful for seaweed cultivation. These systems along with agroforestry-based farming have potential to meet the food and other requirements of saline coastal ecosystem population, especially in the scenario of climate change (Table 7).

Table 7: Different types of marine algae cultivated in India and their uses.

\begin{tabular}{|c|c|c|c|}
\hline Type of algae & Scientific name & Cultivation method & Use \\
\hline \multirow{4}{*}{ Red algae } & $\begin{array}{c}\text { Gracilaria edulis, G. crassa, G. foliifera and } G . \\
\text { verrucosa }\end{array}$ & $\begin{array}{l}\text { Long-line ropes and nets by vegetative } \\
\text { propagation }\end{array}$ & Agar manufacturing \\
\hline & Gracilaria edulis & Single rope floating raft technique & Hydrocolloids \\
\hline & Gelidiella acerosa & $\begin{array}{l}\text { Bottom-culture method using coral stone } \\
\text { as a substratum }\end{array}$ & Hydrocolloids \\
\hline & Kappaphycus alvarezii, & Net bag and raft method & Carrageenan and as food \\
\hline Brown algae & $\begin{array}{c}\text { Sargassum spp., Turbinaria spp. and Cystoseira } \\
\text { trinodis }\end{array}$ & Collection and using nets & $\begin{array}{l}\text { Production of alginates and liquid } \\
\text { seaweed fertilizers }\end{array}$ \\
\hline
\end{tabular}

The island ecosystem offers suitable marine environment for the commercial cultivation of red algae but it is desirable to reduce the bulkiness by preprocessing before sending it to the mainland industries. It is also wise to promote integrated cultivation of shrimps and seaweeds in aquaculture as seaweeds act as scrubbers in reducing nutrient load and cleaning the environment. To utilize seaweed recourses in a sustainable manner, conservation as well as proper husbandry of these resources is a prerequisite. Planned promotion of diversified uses of seaweeds as feed, fodder, feed additives, fertilizers, biocides and antimicrobials will ensure sustained market for seaweeds and provide alternate livelihood to those living in waterlogged-saline areas in Andaman and Nicobar Islands.

\section{Breeding for Tolerance to Salinity, Waterlogging and Inundation}

Salt-tolerant plants can be improved into new, salt (stress) resistant crops, or used as a source of genes to be introduced into conventional crop species that in general have their economical production decreased when soil salt levels increase. As discussed earlier, there are number of salt-tolerant plant species including extreme halophytes which have potential as crops of economic importance. Some of these can directly be domesticated while many others can be explored as gene resources to improve into high yielding salt-tolerant crops.

Salinity affects plant survival and growth because ions (mainly $\mathrm{Na}^{+}$and $\mathrm{Cl}$, but also $\mathrm{Ca}^{2+}$, $\mathrm{Mg}^{2+}$ and $\mathrm{SO}_{4}^{2-}$ ) increase in the soil solution to concentrations that adversely decrease the availability of water to the plant due to the process of exosmosis. Water logging tolerance in crops is primarily associated with two major physiological traits that enable plants to avoid soil hypoxia $[106,107]$. These are, to form root cortex aerenchyma to conduct $\mathrm{O}_{2}$ and ability to form a barrier for radial oxygen loss that decreases its leakage from root inducing more internal diffusion to the tip. Cconventional crop breeding program; for saline, waterlogged and inundation environments; is slow because the plant physiological responses to these stresses are complex with largely unknown genetic basis [108]. Mullan, Bannett Lennard [106] suggested three solutions to overcome the above disadvantages. These include seeking improvement within existing crop genomes; incorporating genetic information from halophytes into crop species; and domesticating the halophytes.

During recent years, some encouraging results have been obtained regarding release of improved salt-tolerant varieties. For example, Kharchia-65 in wheat; and Pokhali and Nona Bokra in rice have given good results. ICAR-Central Soil Salinity Research Institute (CSSRI) in India has developed higher production potential salt-tolerant varieties of rice (CSR 4, CSR 10, CSR 13, CSR 23, CSR 27, Basmati CSR 30, CSR 36 and CSR 43;), wheat (KRL 1-4, KRL 19, KRL 210 and KRL 213), and Indian mustard (CS 52, CS 54, CS 56 and CS 58). Further, three salt-affected varieties of rice (Sumati, Bhootnath and Amalmana) have also been released for coastal agro ecosystem by the Institute's Regional Research Station at Canning Town (West Bengal). They have also developed Canning 7 and Lunishree varieties. CIARI Port Blair has developed CARI Dhan-5 for island conditions. Sources of tolerance to waterlogging (Westonia, KRL 19) and elemental toxicities (KRL 35) in wheat have been identified in an ACIAR (Australian Council of International Agricultural Research) and CSSRI collaborative project [4].

Mackill [109], Xu, Mckill [110], Braun [111] and Ismail et al. [112] described the adaptive mechanism in rice under different hydrological stress environments including salinity and submergence in several released land races such as Samba Mahsuri- 
Sub1 in Nepal, IR 64-Sub1 in Philippines and Indonesia, BR 11Sub1 in Bangladesh and Ciherang-Sub1 in Indonesia. Likewise, Hordeum marinum has been identified as a source of genes for salt and waterlogging tolerance that can be transferred into bread wheat [113]. Yadav [114] reported dual purpose (fodder and grain) potential of Horduem vulgare, under waterlogged saline conditions, which needs morphophysiological characterization for further exploitation in the wake of expected climatic changes. Besides this, protocols have been standardized for in vitro callus transformation in variety F1D 2967 for developing transgenic wheat with enhanced heat tolerance.

From Andaman and Nicobar Island several wild relatives of crop plants are collected and characterized in order to benefit from potential genes from them (Table 8). Fruit species such as Khaariphal (Ardisia solanacea and A. andamanica), Khaarikhajoor (Phoenix paludosa) and legume species Vigna marina are known to grow luxuriantly in coastal saline soils. Oryza indandamanica, a wild rice species reported from these islands, is considered to have physiological traits for drought tolerance (Gautam). Noni (Morinda citrifolia) is adapted to wide range of soil conditions and Rakshak is a promising variety of Noni tolerant to soil salinity. Annona glabra, commonly called as pond apple is observed to be tolerant to salinity and hence could be employed as a rootstock for other cultivated species of this group. A popular aromatic landrace Black Burma can be used as a donor for tolerance to salinity and aluminium toxicity in rice (Mandal).

Table 8: Important wild relatives of crop plants found in Andaman \& Nicobar Islands and their desirable traits.

\begin{tabular}{|c|c|c|}
\hline Wild plants & Botanical name & Desirable traits \\
\hline Khaariphal & Ardisia solanacea and A. andamanica & Salinity tolerant, grows even in waterlogged soils \\
\hline Khaarikhajoor & Phoenix paludosa & Salinity tolerant \\
\hline Legume & Vigna marina & Salinity tolerant \\
\hline \multirow[t]{2}{*}{ Rice } & Oryza indandamanica & Drought tolerance \\
\hline & Black Burma (Oryza sp) & Tolerance to salinity and aluminium toxicity \\
\hline Pond apple & Annona glabra & Salinity tolerant, can be used as root stock \\
\hline Noni & Morinda citrifolia & Salinity tolerant and adapted to hot, humid conditions \\
\hline Knema & Knema andamanica & Can be used as root stock for Nutmeg to provide water stress tolerant \\
\hline Banana & Varieties of Musa acuminata, M. paradisiaca, M. textilis & Drought tolerant \\
\hline Rudraksh & $\begin{array}{l}\text { Varieties of Elaeocarpus sphaericus and many spp of } \\
\text { Elaeocarpus }\end{array}$ & Basic material to improve fruit quality \\
\hline Betel & $\begin{array}{c}\text { Many varieties of Piper betel, P. caninum and other spp of } \\
\text { Piper }\end{array}$ & Base material to improve leaf quality, drought and disease tolerant \\
\hline Mango & Mangifera andamanica, M. camptosperma & Root stock, disease and drought tolerant \\
\hline
\end{tabular}

Spices under organic management have tremendous potential in these islands but suffer from water stress during dry period. Experiments on grafting of cultivated nutmeg (Myristica fragrans) on Knema andamanica (of same family) rootstock have shown 20$30 \%$ success (Rema) and further studies revealed that such grafts were less affected by the water stress [103]. Further research on reducing the incompatibility will pave the way for development of nutmeg for rainfed conditions. A number of wild relatives of different commercial crops have also been reported to occur in the islands and further efforts are needed to conserve and utilize them to develop suitable varieties with desirable traits. Despite the low number of released cultivars for salt and waterlogging tolerance, there exists a large resource of potential germplasm for increasing the genetic base of crop plants. Colmer [115] listed 38 species as possible source of salt tolerance in Triticale, with examples from the Aegilops, Elytrigia, Elymus, Hordium, Leymus, Thinopyrum and Triticum species.

Munns [116] screened 54 Triticum turgidum tetraploids comprising the subspecies durum, turgidum, polonicum, turanicum and carthlicum; and identified large and useful genetic variations for improving the salt tolerance in durum wheat. In another project, around 3000 key rice germplasm has been evaluated for tolerance to submergence, drought and salinity. Six short duration and seven medium and long duration popular rice varieties of Cauvery basin were grown during summer to assess the performance under higher temperature as summer season experienced $3-4^{\circ} \mathrm{C}$ higher than the growing season. Among the tested varieties; ADT 38, ADT 48, CO 43, ADT 36, ADT 37 and BPT 5204 withstood higher temperature and gave higher yields compared to others [117]. This indicates that these varieties can be recommended for the further warmer climate. Legumes are usually salt sensitive but the salt tolerance of Vigna marina along beaches of Andamans has encouraged scientists to inculcate salt-tolerant genes in green gram (Vigna radiata). In future, we can look towards transferring salt-tolerant genes from mangroves to cultivated food crops and fruit trees. Some attempts have been made in this direction by MS Swaminathan Research Foundation, Chennai, India.

\section{Inference}

With decreasing availability of arable land and fresh water for meeting the food requirement of ever-increasing population, we are bound to face the problem of sustainable development of agriculture. Therefore, utilization of salt-tolerant lands and poorquality waters in modern agriculture is inevitable. For this, we 
need innovations in biosaline agriculture by using these lands and salt-tolerant (halophytic) germplasm to develop new crops of high economic importance. Rising temperatures, increased climate variability and extreme weather events could significantly add to the problem having impact on food production, especially in developing countries including India, in the coming decades. The adverse impacts are likely to be more pronounced in already stressed salt-tolerant and drought-prone semi-arid to arid regions of the world [118-132].

Climatic events like cold wave, heat wave, drought, and floods have demonstrated the significant potential of weather factors to influence the production of food crops. Due to sea level rise more areas will be affected by salinity and waterlogging. Therefore, there is an urgent need for using modern science combined with indigenous wisdom of the farmers to enhance the resilience of agriculture to climate change. Development of multiple stress tolerant varieties using wild stress tolerant germplasm, domestication of wild halophytes as food and high value crops, and efficient and diverse agroforestry-based farming systems, which can help in mitigating the adverse impact of climate change and variability. Comparative to conventional crops and glycophytes, the stress tolerant halophytes can withstand the climate related changes in a better way. Further, alternate land use systems like agroforestry and other biological carbon capture systems can also help in both adaptation and mitigation of climate change.

\section{References}

1. Ladeiro B (2012) Saline agriculture in the $21^{\text {st }}$ century: Using salt contaminated resources to cape food requirements: A review. Journal of Botany, p. 7.

2. Dagar JC, Minhas PS (2016) Agroforestry for Management of Waterlogged Saline Soils and poor-quality Waters. Advances in Agroforestry Series, India.

3. Dagar JC, Tomar OS, Minhas PS, Yadav RK, Gajender, et al. (2018) Biomass production of different tree species irrigated with saline groundwater on degraded calcareous soil in dry regions.

4. Dagar JC, Yadav RK (2017) Climate resilient approaches for enhancing productivity of saline agriculture. J Soil Salinity \& Water Quality 9(1): 9-29.

5. Glenn EP, Brown JJ, Blumwald E (1999) Salt tolerance and crop potential of halophytes. Critical Reviews in Plant Sciences 18(2): 227-255.

6. Boyko H (1966) Salinity and Aridity: New Approach to Old Problems. The Hague, pp. 408.

7. Epstein E, Norlyn JD, Rush DW (1980) Saline culture of crops: A genetic approach. Science 210 (4468): 399-404.

8. Aronson J (1989) Haloph: A Data Base of salt-tolerant Plants of the World. Arid Land Studies. The Tucson, Arizona, p. 75.

9. Glenn EP, Hicks N, Riley J, Swingle S (1995) Seawater irrigation of halophytes for animal feed. In: Halophytes and Biosaline Agriculture. Marcel Dekker, New York, USA.

10. Dagar JC (2003) Biodiversity of Indian saline habitats and management and utilization of high salinity tolerant plants with industrial application for rehabilitation of saline areas. In: Alsharhan AA, Wood WW, Gouie AS, Fowler A, Abdellatif EM (eds); Desertification in the Third Millennium. Swets and Zeitlinger Publishers, Lisse, The Netherlands, pp. 151-172.
11. Dagar JC, Singh Gurbachan (2007) Biodiversity of Saline and Waterlogged Environments: Documentation, Utilization and Management. National Biodiversity Authority, India, p.76.

12. Dagar JC, Jat ML, Sapkota TB, Yadvinder Singh, Govaerts B, et al. (2016) Climate change and agriculture: Adaptation strategies and mitigation opportunities for food security in South Asia and Latin America. Advances in Agronomy 137: 127-236.

13. Yensen NP, Bedell JL, Yensen SB (1988) The history of the development of Distichlis cultivars for grain, forage and slad. Proc Mexican National Conference on Halophytes. Ciudad Obregon, Sonora, Mexico.

14. NRC (1990) Saline Agriculture: Salt-tolerant Plants for Developing Countries. National Research Council (NRC), National Academy Press, Washington DC, pp. 143.

15. Jaradat AA (2003) Halophytes for sustainable farming systems in the Middle East. In: Alsharhan AS, Wood WW, Goudie AS, Fowler A, Abdellatif EM (Eds); Desertification in the Third Millennium. Swets \& Zeitlinger Publishers, Lisse, The Netherlands, pp. 187-204.

16. Galvani A (2007) The challenge of food sufficiency through Salt-tolerant crops. Reviews in Environmental Sci and Biotechnology 6 (1-3): 3-16.

17. Barnes RF, Baylor JE (1995) Forages in a changing world. In: Forages: An Introduction to Grassland Agriculture. ( $6^{\text {th }}$ edn); State Univ Press, New York, USA, pp. 576.

18. Alsharhan AS, Wood WW, Gouie AS, Fowler A, Abdellatif EM (2003) Desertification in the Third Millennium. Swets and Zeitlinger Publishers, Lisse, The Netherlands, pp. 489.

19.Zhang JY, Wang ZY, Jenks MA, Hasegawa PM, Jain SM (2007) Recent advances in molecular breeding of forage crops for improved drought and salt stress tolerance. In: Advances in Molecular Breeding towards Salinity and Drought Tolerance. Springer, pp. 797-817.

20. Rozema J, Muscolo A, Flowers T (2013) Sustainable cultivation and exploitation of halophyte crops in a salinising world. Environ Exper Bot 92: 1-3.

21. Panta S, Flowers T, Lane P, Doyle R, Haros G (2014) Halophytes agriculture: Success stories. Environ Experimental Bot 107: 71-83.

22. Lenssen GM, Van Duin WE, Jak P, Rozema J (1995) The response of Aster tripolium and Puccinellia maritima to atmospheric carbon dioxide enrichment and their interactions with flooding and salinity. Aquatic Botany 50(2): 181-192.

23. Dagar JC (2014) Greening salty and waterlogged lands through agroforestry systems for livelihood security and better environment. In: Dagar JC, Singh A, Arunachalam A (Eds.); Agroforestry Systems in India: Livelihood Security \& Environmental Services-Advances in Agroforestry Springer New York, USA pp. 273-332.

24. Velmurugan A, Dam Roy S, Dagar JC, Swarnam TP, Jaisankar I (2016) Innovative technologies to sustain saline island agriculture in the scenario of climate change: A case study from Andaman Islands, India. In: Dagar JC, Sharma PC, Sharma DK, Singh AK (Eds.); Innovative Saline Agriculture. Springer, India, pp. 387-417.

25. Li FS, Yu JM, Nong ML, Kang SZ, Zhang JH (2010) Partial Root-Zone irrigation enhanced soil enzyme activities and water use of maize under different ratios of inorganic to organic nitrogen fertilizers. Agric Water Manage 97(2): 231-239.

26. Abideen Z, Ansari R, Khan MA (2011) Halophytes: Potential source of ligno-Cellulosic biomass for ethanol production. Biomass Bioenergy 35(5): 1818-1822.

27. Dagar JC, Pandey CB, Chaturvedi CS (2014) Agroforestry: A way forward for sustaining fragile coastal and island Agro-Ecosystems. In: Dagar JC, Singh AK, Arunachalam A (eds) Agroforestry Systems in India: Livelihood Security \& Environmental Services. Advances in Agroforestry New York, USA pp. 185-232.

28. Dagar JC, Tomar OS, Minhas PS, Kumar M (2013) Lemon grass 
productivity as affected by salinity of irrigation water, planting methods and fertilizer doses on a calcareous soil in a semiarid region of northwest India. Indian Journal of Agricultural Sciences 83(7): 734-738.

29. CSIR (1986) The Useful Plants of India. Council of Scientific \& Industrial Research (CSIR), New Delhi.

30. Dagar HS, Dagar JC (1991) Plant folk medicines among the Nicobarese. Economic Botany 45(1): 114-119.

31. Tomar OS, Minhas PS, Dagar JC (2005) Isabgol (Plantago ovataForsk): A Potential Crop for Saline Irrigation and Moderate Alkali Soils. CSSRI, Karnal, India, p. 17.

32. Dagar JC, Hari Bhagwan, Kumar Y (2004) A Effect on growth performance and biochemical contents of Salvadora persica when irrigated with water of different salinity. Indian Journal of Plant Physiology 9(3): 234-238.

33. Dagar JC, Kumar Y Tomar OS (2006) Cultivation of medicinal Isabgol (Plantago ovata) in alkali soils in semiarid regions of northern India. Land Degradation and Development 17(3): 275-283.

34. Dagar JC (2017) A Potentials for fodder production in degraded lands. In: Ghosh PK, Mohanta SK, Singh JB, Vijay D, Kumar RV, et al. (Eds.); Approaches Towards Fodder Security in India. Studera Press New Delhi, pp. 333-364.

35. Dagar JC, Ahamad S (2017) Isabgol. In: Peter KV Horticultural Crops of High Nutritive Values. Brillion Publishing, New Delhi, pp. 261-276.

36. Dagar JC, Dagar HS (1999) Ethnobotany of Aborigines of AndamanNicobar Islands. Surya International Publications, Dehra Dun, India, p. 203.

37. Dagar JC, Singh NT (1999) Plant Resources of the Andaman \& Nicobar Islands. Bishen Singh Mahendra Pal Singh, Dehra Dun, India, p. 987.

38. Pasternak D, Aronson JA, Ben Dov J, Forti M, Mendlinger S, et al. (1986) Development of new arid zone crops for the Negev Desert of Israel. J Arid Environments 11: 37-59.

39. Khan MA, Ansari R, Gul B, Qadir M (2006) Crop diversification through halophyte production on salt prone land resources. CAB Reviews 1: 1-9.

40. Dagar JC (1996) Rehabilation of coastal saline lands by planting with suitable species. Journal Indian Soc Coastal Agril Res 14(1,2): 185-191.

41. Dagar JC (2008) Indian mangroves: Status, management and their plausible benefits for livelihood security. J Indian Soc Coastal Agricultural Research 26(2): 121-128.

42. Dagar JC (2012) Utilization of degraded lands / habitats and poor quality water for livelihood security and mitigating climate change. Indian Journal of Agroforetsry 14(1): 1-16.

43. Dagar JC (2016) Agroforestry: Four decades of research developments. Indian J Agroforestry 18(2): 1-32.

44. Dagar JC, Gupta SR (2016) Agroforestry: Potentials for rehabilitation of degraded lands, constraints and the way forward. In: Dagar JC, Tewari JC (Eds.), Agroforestry Research Developments. Nova Science Publishers, Inc, New York, USA, pp. 46-97.

45. Shannon MC (1997) Adaptation of plants to salinity. Advances in Agr 60: 75-120.

46. Shannon MC (1997) Genetics of salt tolerance in higher plants. In: Jaiwal PK, Singh RP, Gulati A (Eds.), Strategies for Improving Salt Tolerance in Higher Plants. Oxford \& IBH Pub. New Delhi, India, pp. 265-289.

47. Mishra A, Tanna B (2017) Halophytes: Potential resources for salt stress tolerance genes and promoters. Frontiers in Plant Sci 8: 829.

48. Keiffer CH, Ungar IA (1997) The effect of extended exposure to hypersaline conditions on the germination of five inland halophyte species. American J Bot 84(1): 104-111.

49. Dagar JC, Lal K, Jeet Ram, Mukesh Kumar, Yadav RK, et al. (2016) Eucalyptus geometry in agroforestry on waterlogged saline soils influences plant and soil traits in North-West India. Agriculture Ecosystems and Environment 233(3): 33-42.

50. Aslam Z, Awan AR, Rizwan M, Gulnaz A, Malik KA (2009) Government Report on Saline Agriculture Farmer Participatory Development Project in Pakistan. Nuclear Institute for Agriculture \& Biology (NIAB), Pakistan Atomic Energy Commission, Faisabad, Pakistan, p. 1-57.

51. Quadir M, Oster JD (2004) Crop and irrigation management strategies for saline sodic soils and waters aimed at environmentally sustainable agriculture. Science Total Environ 323(1-3): 1-19.

52. Lambert M, Turner J (2000) Commercial Forest Plantations on Saline Land. CSIRO Publishing, Collingwood, Australia.

53. Singh G, Dagar JC (2005) Greening Sodic Soils: Bichhian Model. Technical Bulletin Central Soil Salinity Research Institute, Karnal, p. 51

54. Barrett-Lennard EG (2003) Salt Land Pastures in India: A Practice Guide. State of Western Australia, Dept of Agriculture, CISRO, CRC for Plant based Management of Dryland Salinity Australia, pp. 176.

55. Bell DT (1999) Australian trees for rehabilitation for waterlogged and salinity damaged landscapes. Australian Journal of Botany 47(5): 697716.

56. Dagar JC, Sharma HB, Shukla YK (2001) Raised and sunken bed technique for agroforestry on alkali soils of northwest India. Land Degradation \& Development 12(2): 107-118.

57. Dagar JC, Singh G, Singh NT (2001 ) Evaluation of forest and fruit trees used for rehabilitation of Semiarid alkali sodic soils in India. Arid Land Research and Management 15(2): 115-133.

58. Marcar NE, Crawford DF (2004) Trees for Saline Landscapes. Rural Industries Development and Research Corporation. Kingston, pp. 235.

59. Zhang JY, Xing S, Li J, Makeschin F, Song Y (2004) Agroforestry and its application in amelioration in saline soils in eastern China coastal region. Forest Study China 6(2): 27-33.

60. Masters DG, Benes SE, Norman HC (2007) Biosaline agriculture for forage and livestock production. Agric Ecosystems \& Environ 119(3-4): 234-248.

61. Singh G, Singh NT, Dagar JC, Singh H, Sharma VP (1997) An evaluation of agriculture, forestry and agroforestry practices in a moderately alkali soil in northwestern India. Agroforestry Systems 37(3): 279-295.

62. Stille L, Sweets E, Wicke B, Singh RK, Singh G (2011) The economic performance of four (agro)forestry systems on sodic soils of Haryana, India. Energy Sus dev 15(4): 388-397.

63. Kaur B, Gupta SR, Singh G (2002) Bioamelioration of a sodic soil by silvopastoral system in northwestern India. Agroforestry Systems 54(1): $13-20$

64. Lal R (2009) Carbon sequestration in saline soils. J Soil Salinity \& Water Quality 1(1-2): 30-40.

65. Wong VNL, Greene RSB, Dalal RC, Murphy B (2009) Soil carbon dynamics in saline and sodic soils: a review. Soil Use Manage 26(1): 2-11.

66. Oliver EE (1881) Report on Reh-Swamp and Drainage of the Western Jamuna Canal Districts. Public Works Department Press, Lahore.

67. Leather JW (1897) Agricultural Ledger. pp. 129-137.

68. Moreland WH (1901) Reh. Agricultural Ledger 13: 415-463.

69. Sandhu SS, Abrol IP (1981) Growth response of Eucalyptus tereticornis and Acacia nilotica to selected cultural treatments in a highly sodic soil. Indian J Agric Sci 51: 437-443.

70. Singh G, Gill HS (1992) Ameliorative effect of tree species on characteristic of sodic soils at Karnal. Indian J Agri Sci 62(2): 142-146.

71. Singh UN, Bhatt DN, Yadav JSP (1987) Growth and biomass production of certain forest species as influenced by varying $\mathrm{pH}$ levels. In: Proceedings 
of International Symposium on Afforestation of salt-affected Soils. CSSRI, Karnal, India 2: 51-62.

72. Singh YP, Sharma DK, Singh G, Nayak AK, Mishra VK, et al. (2008) Alternate Land Use Management for Sodic Soils. CSSR Technical Bull. CSSRI, Karnal, p. 16.

73. Dagar JC, Tomar OS, Kumar Y, Yadav RK (2004) Growing three aromatic grasses in alkali soils in semi-arid regions of northern India. Land Degradation \& Development 15(2): 143-151.

74. AICRP (2000-2004) Biennial Reports of the All India Coordinated Research Project on Management of salt-affected Soils and Use of Saline Water in Agriculture. CSSRI, Karnal, India. pp. 1-230.

75. Dagar JC, Kumar Y Tomar OS (2006) Cultivation of medicinal Isabgol (Plantago ovata) in alkali soils in semiarid regions of northern India. Land Degradation and Development 17(3): 275-283.

76. Dagar JC, Gururaja Rao G, Shukla YK, Sharma HB (2009) Performance of three flower yielding plants in different sodic soils. Indian J Horticulture 66(3): 404-409.

77. Dagar JC, Yadav RK, Dar SR, Sharif Ahamad (2015) Liquorice (Glycyrrhiza glabra): A potential salt-tolerant highly remunerative medicinal crop which also helps in remediation of alkali soils. Current Science 108(9) 1683-1688.

78. Tomar OS, Gupta RK, Dagar JC (1998) Afforestation techniques and evaluation of different tree species for waterlogged saline soils in semiarid tropics. Arid Soil Research \& Rehabilitation 12(4): 301-316.

79. Dam Roy S (2003) A Compendium on Mangrove Biodiversity of Andaman and Nicobar Islands. Central Agricultural Research Institute, Port Blair, India, p 196.

80. Goutham Bharathi MP, Dam Roy S, Krishnan P, Kaliyamoorthy M, Immanuel T (2014) Species diversity and distribution of mangroves in Andaman and Nicobar Islands, India. Botanica Marina 57(6): 421-432.

81. Heuperman AF, Kapoor AS, Denecke HW (2002) Biodrainage: Principles, Experiences and Applications. Intnl. Programme for Technology \& Research in Irrigation and Drainage. IPTRID Secretariat, FAO, Rome, p. 78.

82. Dagar JC, Tomar OS, Minhas PS, Singh G, Jeet Ram (2008) Dryland Biosaline Agriculture-Hisar Experience. Techanical Bulletin 6, CSSRI, Karnal, p. 28.

83. Benyon RG, Marcar NE, Crawford DF, Nicholson AT (1999) Growth and water use of Eucalyptus camaldulensis and E. occidentalis on a saline discharge site near Wellington, NSW, Australia. J Agri Water Manage 39(2-3): 229-244.

84. Cramer VA, Thornburn PJ, Fraser DW (1999) Transpiration and ground water uptake from farm forest plots of Casuarina glauca and Eucalyptus camaldulensis in saline areas of south east Queensland, Australia. Agric Water Manage 39(2-3): 187-204.

85. Dagar JC, Sharma PC, Sharma SK, Singh AK (2016) Innovative Saline Agriculture. Springer, New Delhi, India pp. 519.

86. Hubbard RM, Stape Jl, Ryan MG, Almieida AC, Rojas J (2010) Effects of irrigation on water use and water use efficiency in two fast growing Eucalyptus plantations. Forest Ecol Manage 259(9): 1714-1721.

87. Chauhan MK, Ram J, Dagar JC (2012) Biodrainage and Carbon Sequestration. Lap Lambert Academic Publishing, pp. 304.

88. Kapoor AS (2014) Managing Groundwater for Irrigated Agriculture: The Relevance of Biodrainage Model. Rawat publications, Jaipur, pp. 341.

89. Jeet Ram, Dagar JC, Lal K, Singh G, Toky OP, et al. (2011) Biodrainage to combat water logging, increase farm productivity and sequester carbon in canal command area of north west India. Current Science 100(11): 1673-1680.
90. Tomar OS, Minhas PS (2002) Performance of some ornamental winter annual flowering species under saline irrigation. Indian Journal Horticulture 59(2): 201-206.

91. Tomar OS, Minhas PS (2004) Relative performance of aromatic grasses under saline irrigation. Indian Journal of Agronomy 49(3): 207-208.

92. Tomar OS, Minhas PS, Sharma VK, Gupta RK (2003) Response of nine forage grasses to saline irrigation and its schedules in a semi-arid climate of north west India. Journal of Arid Environments 55(3): 533-544.

93. Dagar JC, Yadav RK, Minhas PS, Tomar OS, Gajender (2015) Fruit based agroforestry systems for saline water irrigated semiarid hyperthermic camborthids regions of north west India. Agroforestry Systems 90: 1123-1132.

94. Dagar JC, Tomar OS, Kumar Y, Hari Bhagwan, Yadav RK, et al. (2006) Performance of some under-explored crops under saline irrigation in a semiarid climate in northwest India. Land Degradation \& Development 17(3): 285-299.

95. Tomar OS, Minhas PS, Sharma VK, Singh YP, Gupta RK (2003) Performance of 31 tree species and soil condition in a plantation established with saline irrigation. Forest Ecology and Management 177(1-3): 333-346.

96. Yadav RK, Singh SP, Lal D, Kumar A (2007) Fodder production and soil health with conjunctive use of saline and good quality water in ustipsamments of a semiarid region. Land Degradation \& Development 18(2): 153-161.

97. Tomar OS, Dagar JC Minhas PS (2010) Evaluation of sowing methods, irrigation schedules, chemical fertilizer doses and varieties of Plantago ovata Forsk to rehabilitate degraded calcareous lands irrigated with saline water in dry regions of north western India. Arid Land Research \& Management 24(2): 133-151.

98. Gururaja Rao G, Arora S, Chinchmalatpure AR (2016) Use of saline water/industrial effluents in diverse crop interventions in Vertisols. In: Dagar JC, Sharma PC, Sharma DK, Singh AK (Eds.), Innovative Saline Agriculture. Springer India, pp. 277-302.

99. Burman D, Bandyopadhyay BK, Mandal S, Subhasis, Mandal UK, et al. (2013) Land shaping - A unique technology for improving productivity of coastal land, Bulletin No. CSSRI/Canning Town/Bulletin/2013/02. Central Soil Salinity Research Institute, Regional Research Station, Canning Town, West Bengal, India, p. 38.

100. Burman D, Mandal S, Bandopadhyay BK, Maji B, Sharma DK, et al. (2015) Unlocking production potential of degraded coastal land through innovative land management practices: A synthesis. J Soil Salinity Water Qual 7(1): 12-18.

101. Mandal S, Burman D, Sarangi SK, Maji B, Bandyopadhyay BK (2016) Homestead production systems in coastal salt-affected areas of Sunderbans: status and way forward strategies. In: Dagar JC, Sharma PC, Sharma SK, Singh AK (eds); Innovative Saline Agriculture. Springer, New Delhi, India pp. 371-385.

102. McHugh DJ (2003) A guide to the seaweed industry. FAO Fish Technical Paper 441, pp. 1-118.

103. Krishnamurthy V (2005) Seaweeds: Wonder Plants of the Sea. Aquaculture Foundation of India, Chinnai, p. 30.

104. NASS (2003) Seaweed Cultivation and Utilization. Policy Paper No. 22. National Academy of Agricultural Sciences (NAAS), New Delhi, India p. 1-6.

105. Seth A, Shanmugam M (2016) Seaweeds as agricultural crops in India: New vistas. In: Dagar JC, Sharma PC, Sharma DK, Singh AK (eds); Innovative Saline Agriculture. India pp. 441-473.

106. Mullan DJ, Barrett Lennard EG (2010) Breeding crops for tolerance to salinity, waterlogging and inundation. In: Reynolds MP Climate Change \& Crop Production. CABI Climate Change Series. CAB International, Oxfordshire, UK, pp. 92-114. 
107. Flowers TJ, Galal HK, Bromham L (2010) Evaluation of halophytes: Multiple origins of salt tolerance in land plants. Functional Plant Biol 37: 604-612.

108. Flowers TJ (2004) Improving crop salt tolerance. Journal of Experimental Botany 55(396): 307-319.

109. Mackill DJ, Coffman WR, Garrity DP (1996) Rainfed Lowland Rice Improvement. International Rice Research Institute, Los Banos, The Philippines, pp. 1-258.

110. Xu K, Mackill DJ (1996) A major locus for submergence tolerance mapped on rice chromosome 9. Molecular Breeding 2(3): 219-224.

111. Braun HJ, Atlin G, Payne T (2010) Multi-Location testing as a tool to identify plant response to global climate change. In: Reynolds MP Climate Change \& Crop Production. CABI Climate Change Series, CAB International, Oxfordshire, UK, pp. 115-138.

112. Ismail AM, Singh U, Singh S, Dar MH, Mackill DJ (2013) The contribution of submergence-tolerant (Sub-1) rice varieties to food security in flood-prone rainfed lowland areas in Asia. Field Crops Research 152: 83-93.

113. Colmer TD, Munns R, Flowers TJ (2005) Improving salt tolerance of wheat and barley: Future prospects. Australian Journal of Experimental Agriculture 45(11): 1425-1443.

114. Yadav RK, Kumar A, Lal D (2003) Effect of cutting management and nitrogen levels on biomass production and proximate quality of barley (Hordeum vulgare) in saline soil. Indian Journal of Agronomy 48(3): 199-202.

115. Colmer TD, Flowers TJ, Munns R (2006) Use of wild relatives to improve salt tolerance in wheat. Journal of Experimental Botany 57(1): 1059-1078.

116. Munns R, Hare RA, James RA, Rebetzke GJ (2000) Genetic variation for improving the salt tolerance of durum wheat. Australian Journal of Agricultural Research 51(1): 69-74.

117. Geethalakshmim V, Lakshmanan A, Rajalakshmi D, Jagannathan R, Sridhar G, et al. (2011) Climate change impact assessment and adaptation strategies to sustain rice production in Cauvery basin of Tamil Nadu. Current Science 101(3): 342-347.

118. CDIAC (2016) Global Carbon Budget 2016, Carbon Dioxide Information Center.

119. Choudhary OP (2016) Innovations in sodic water irrigation management. In: Dagar JC, Sharma PC, Sharma SK and Singh AK (eds); Innovative Saline Agriculture. Springer, New Delhi, India pp. 201-217.

120. (2018) Climate Central. USA.

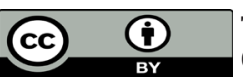

This work is licensed under Creative Commons Attribution 4.0 License

To Submit Your Article Click Here: Submit Article

DOI: $10.32474 /$ SJFN.2018.01.000115
121. Dagar JC (2005) Ecology, management and utilization of halophytes. Bulletin of the National Institute of Ecology 15: 81-97.

122. Dagar JC (2017) Liquorice In: Peter KV Horticultural Crops of High Nutritive Values. Brillion Publishing, New Delhi, India pp. 277-286.

123. Dagar JC, Singh NT, Mongia AD (1993) Characteristics of mangrove soils and vegetation of Bay Islands in India. In: Lieth $\mathrm{H}, \mathrm{Al}$ Masoom AA (Eds.), Towards the Rational Use of High Salinity Tolerant Plants. Kluwer Academic Publishers Netherlands, pp. 59-80.

124. IPCC (2007) Intergovernmental Panel on Climate Change Fourth Assessment Report: Climate Change, Geneva.

125. IPCC (2014) Climate Change 2014: Impacts, Adaptation and Vulnerability. Summary for Policymakers. IPCC WGII AR5, Phase I Report Launch, pp. 44.

126. Jat HS, Singh G, Singh R, Choudhary M, Gathala MK, et al. (2016) Management influence on maize wheat system performance, water productivity and soil biology. Soil Use and Management 31(4): 534543.

127. Koyro HW, Geissler N, Hussin S, Huchzermeyer B (2006) Mechanisms of cash crop halophytes to maintain yields and reclaim saline soils in arid areas. In: Khan MA and Weber DJ (Eds.), Ecophysiology of High Salinity Tolerant Plants. Springer, Amesterdam 40: 345-366.

128. NASA/NOAA (2017) NASA, NOAA-Press release to announce 2017 global temperatures, climate condition. National Aeronautics \& Space Administration; and National Oceanic \& Atmospheric Administration, US Dept of Commerce, USA.

129. Singh KN Chatrath R (2001) Salinity tolerance. In: Reynold MP, Ortiz Monasterrio JI, McNab A Application of Physiology in Wheat Breeding. International Maize and Wheat Breeding Center (CIMMYT), Mexico DF, pp. 1-246.

130. Tomar OS, Dagar JC, Singh YP (2004) Forest and fruit trees for alkali soils. Indian Farming 53(11): 44-47.

131. Wicke B, Smeets EMW, Akanda R, Stille L, Singh RK, et al. (2013) Biomass production in agroforestry and forestry systems on saltaffected soils in South Asia: exploration of the GHG balance and economic performance of three case studies. J Environ Management 127: 324-334

132. WMO (2009) WMO's Global Atmosphere Watch Program. World Meteorological Organization, Atmospheric Environmental Research Division, Geneva.

133. Khan SA (2003) Studies on sodic soils through agroforestry system for central plain zone of Uttar Pradesh, India. Paper in XII World Forestry Congress, Canada.

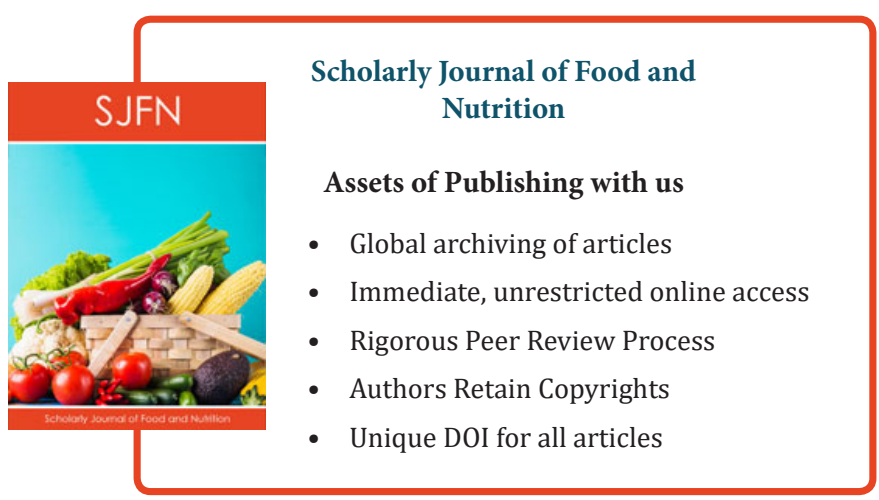

